\title{
POTENSI AKAR KUNING (Fibraurea tinctoria Lour.) DI HUTAN RAWA GAMBUT, KABUPATEN KAPUAS, PROVINSI KALIMANTAN TENGAH (Potential of akar kuning (Fibraurea tinctoria Laur.) in Peat-Swamp Forests, Kapuas District, Central Kalimantan Province)
}

\section{Titi Kalima}

\author{
Pusat Penelitian dan Pengembangan Hutan \\ Jln. Gunung Batu P.O Box 165 Bogor, 16001, Indonesia \\ Telp: (0251) 8633234; 7520067; fax (0251) 8638111 \\ E-mail: titi_kalima@yahoo.co.id
}

Tanggal diterima: 2 Juli 2020; Tanggal disetujui: 23 Februari 2021; Tanggal direvisi : 23 Februari 2021

\begin{abstract}
Peat swamp forests in Kalimantan have generally been damaged due to overexploitation and excessive human activities. Akar kuning plant (Fibraurea tinctoria Laur.) is known as a traditional herbal medicine used by Central Kalimantan people. This study aimed to obtain data on the potential, distribution, and association of akar kuning in the Block Release Forest, Mantangai District, Kapuas Regency, Central Kalimantan Province. Data collection was conducted with an inventory purposive sampling method, where two transect lines were made and placed in the location where akar kuning was observed. Then 80 sampling units with a size of $5 m \times 5 m$ and $2 m \times 2 m$ were made alternately with an area of 0.2 ha. The results showed that the potential of Fibruarea tinctoria in the Block Release forest was 375 individuals/ha and 675 individuals/ha, where the seedling phase is more dominant than the sapling phase (40 individuals/ha and 70 individuals/ha). The akar kuning distribution pattern was also found to spread uniformly or regularly. The level of association measured using the Ochiai index (OI) indicated that the most significant value of association strength was owned by Shorea balangeran and Mangifera similis $(O I=0.63)$, while the presence of Freycinetia angustifolia had a low level of association $(O I=0.48-0.23)$. Meanwhile, the lowest level of association $(O I=<0.22)$ was found in 17 species. Plant species associated with Fibraurea tinctoria are usually having potential as medicinal raw materials. Information regarding population, distribution and distribution patterns, as well as the association of akar kuning, is expected to be the basis for sustainable management of akar kuning in nature.
\end{abstract}

\section{Keywords: Potential, Fibraurea tinctoria, Block Release Forest}

\begin{abstract}
ABSTRAK
Hutan rawa gambut Kalimantan umumnya telah mengalami kerusakan karena adanya eksploitasi dan aktivitas manusia yang berlebihan. Tumbuhan akar kuning (Fibraurea tinctoria Laur.) dikenal sebagai obat herbal yang digunakan secara tradisional oleh masyarakat Kalimantan Tengah. Penelitian ini bertujuan untuk memperoleh informasi potensi, sebaran, dan asosiasi akar kuning di Hutan Blok Release, Kecamatan Mantangai, Kabupaten Kapuas, Provinsi Kalimantan Tengah. Pengambilan data dilakukan dengan cara inventarisasi dengan metode pengambilan contoh secara purposif, dibuat dua jalur transek dan peletakan jalur (transek) pada lokasi ditemukan tumbuhan akar kuning. Kemudian dibuat plot berukuran $5 \mathrm{~m} \times 5 \mathrm{~m}$ dan $2 \mathrm{~m} \times 2 \mathrm{~m}$ secara selang seling sebanyak 80 plot dengan luasan 0,2 ha. Hasil penelitian menunjukkan bahwa potensi Fibraurea tinctoria di hutan Blok Release adalah 375 individu/ha dan 675 individu/ha, dimana tingkat semai lebih dominan
\end{abstract}


daripada tingkat pancang (40 individu/ha dan 70 individu/ha). Adapun pola sebaran akar kuning menyebar secara seragam atau teratur. Tingkat asosiasi menggunakan indeks Ochiai (OI), menunjukkan nilai kekuatan asosiasi yang terbesar dimiliki oleh Shorea balangeran dan Mangifera similis (OI $=0,63)$, kehadiran Freycinetia angustifolia memiliki tingkat asosiasi rendah $(\mathrm{OI}=0,48-0,23)$ dan tingkat asosiasi terendah $(\mathrm{OI}=<0,22)$ dtemukan pada 17 jenis. Jenis tumbuhan yang berasosiasi terhadap Fibraurea tinctoria adalah tanaman yang berpotensi sebagai bahan baku obat. Informasi mengenai populasi, sebaran dan pola sebaran, serta asosiasi akar kuning, diharapkan dapat menjadi dasar dalam pengelolaan akar kuning secara lestari di alam.

\section{Kata kunci: Potensi, Fibraurea tinctoria, Hutan Blok Release}

\section{PENDAHULUAN}

Hutan tropis di Indonesia adalah wilayah hutan dengan keanekaragaman hayati paling beragam dan produktif (Brandon, 2014) dengan ekosistem hutan tropis terbesar di dunia (Gaither, 2013). Indonesia merupakan negara kepulauan yang memiliki lebih dari 25.000-30.000 spesies tumbuhan dan tipe ekosistem yang beragam (Kartawinata, 2010). Kalimantan sebagai salah satu sumber plasma nutfah yang memiliki potensi keanekaragaman hayati yang tinggi dan didominasi oleh spesies Dipterocarpaceae (de Bruyn et al., 2014); (Brearley, Banin, \& Saner, 2016). Tingginya keanekaragaman hayati, menempatkan Indonesia sebagai laboratorium alam yang sangat unik untuk tumbuhan tropik dengan berbagai fenomenanya. Salah satunya spesies tumbuhan akar kuning (Fibraurea tinctoria Lour.) yang menjadi perhatian dalam penelitian ini. Di Indonesia, ditemukan tiga spesies Fibraurea, yaitu F. darshanii Udayan \& K.Ravik., F. recisa Pierre, dan F. tinctoria Lour. (Govaerts, 2001).

Fibraurea tinctoria adalah spesies tumbuhan liana berkayu, memanjat, dari famili Menispermaceae (Setyawati, 2015), banyak ditemukan di hutan rawa gambut yang terbuka dan agak teduh di Sumatera, Jawa, Kalimantan, Sulawesi, Halmahera, Filipina, Thailand, Indocina dan Malaya (Sinaga, Tobing, \& Pravita, 2016; Rinaldi, Suryanto, \& Widuri, 2017). Masyarakat sekitar hutan menggunakan tumbuhan F. tinctoria sebagai bahan baku obat tradisional untuk pengobatan penyakit yang berhubungan dengan gangguan fungsi hati seperti liver, penyakit malaria, diabetes dan penyakit kuning karena tumbuhan $\mathrm{F}$. tinctoria mengandung berbagai zat alami, seperti senyawa berberin (Ahmed, Gilani, Abdollahi, Daglia, Nabavi, \& Nabavi, 2015). Selain untuk keperluan pengobatan tradisional, industri jamu dan farmasi juga menggunakan akar kuning sebagai salah satu komoditi bahan baku biofarmaka di sektor kehutanan (Indartik, 2009; Rinaldi, Suryanto, \& Widuri, 2017).

Blok Release merupakan kawasan lindung dengan topografi relatif datar, berawa dengan tipe ekosistem air hitam (Badan Planologi Kehutanan, 2007) sebagai habitat tumbuhan F. tinctoria. Kondisi hutannya relatif terganggu, akibat kegiatan eksploitasi besar-besaran, sehingga populasi F. tinctoria dan pohon rambatan menurun. Oleh karena itu, penelitian potensi tumbuhan akar kuning (F. tinctoria) dengan latar belakang kondisi habitat akar kuning di Blok Release mengalami eksploitasi.

Sehubungan dengan hal ini, inventarisasi dan komposisi tumbuhan spesies F. tinctoria terhadap lingkungan ekologisnya perlu dilakukan. Penelitian bertujuan untuk mengetahui potensi tumbuhan F. tinctoria sebagai bahan baku obat oleh masyarakat setempat dari hutan alam Blok Release di Kabupaten Kapuas, Provinsi Kalimantan Tengah. 


\section{METODOLOGI}

\section{A. Lokasi dan Waktu Penelitian}

Lokasi penelitian terletak di kelompok Hutan Tabati, Blok Release, Kecamatan Mantangai, Kabupaten Kapuas, Kalimantan Tengah. Secara geografis, hasil pengukuran koordinat lokasi kelompok Hutan Tabati terletak diantara $02^{\circ} 18^{\prime} 24,6$ Lintang Selatan dan 114'34'16" Bujur Timur. Lokasi penelitian terletak pada ketinggian 50-285 $\mathrm{m}$ dpl. Topografi lokasi penelitian landai. Iklim tropis dan lembab dengan curah hujan berkisar 2.000-3.000 mm tiap tahun dan temperatur berkisar antara $21-23^{\circ} \mathrm{C}$. Habitat hutan rawa gambut $\mathrm{F}$. tinctoria menjadi lokasi pengambilan sampel (Gambar 1).

\section{B. Metode}

\section{Ekspolasi potensi tumbuhan akar kuning}

Pendataan akar kuning (F. tinctoria) dilakukan dengan eksplorasi di hutan rawa gambut Blok Release, Blok Release termasuk ekosistem air hitam dengan luas 22.029 ha (Badan Planologi Kehutanan, 2007). Kemudian dilakukan inventarisasi F. tinctoria tingkat semai dan tingkat pancang pada lingkungan ekologisnya. Tumbuhan F. tinctoria adalah kelompok liana berkayu, herba, dan perdu (Tudjuka, Ningsih, \& Toknok, 2014).

\section{Penentuan petak ukur}

Pengumpulan data vegetasi menggunakan metode jalur berpetak, penempatan jalur pertama secara sengaja (purposive sampling) pada lokasi yang ditemukan F. tinctoria, kemudian membuat plot $5 \mathrm{~m}$ x $5 \mathrm{~m}$ (tingkat pancang) dan sub plot $2 \mathrm{~m} \times 2 \mathrm{~m}$ (tingkat semai) secara selangseling. Setiap jalur dibuat sepanjang $1 \mathrm{~km}$ dan lebar $10 \mathrm{~m}$ (5 m di sebelah kiri dan $5 \mathrm{~m}$ sebelah kanan jalur), sebanyak 2 jalur. Jumlah total plot pengamatan 80 plot dengan luas 0,2 ha (Gambar 1). Dalam penelitian ini tidak menghitung vegetasi tingkat tiang dan pohon, karena spesies tumbuhan F. tinctoria termasuk tumbuhan liana berkayu merambat yang mempunyai diameter kurang dari $5 \mathrm{~cm}$, sehingga tumbuhan tersebut dimasukkan ke dalam tingkat pancang (Page, Rieley, Shotyk, \& Weiss, 1999). Untuk kriteria pengelompokan diameter F. tinctoria, semai tinggi $<1,5 \mathrm{~m}$, pancang tinggi $\geq 1,5 \mathrm{~m}$ dan diameter $\leq 10 \mathrm{~cm}$ (Soerianegara, \& Indrawan, 2008). Data yang dicatat berupa nama jenis tumbuhan dan jumlah individu, dibedakan menurut tingkat pertumbuhan (tumbuhan semai dan pancang). Data penemuan akar kuning berdasarkan hasil eksplorasi tersebut kemudian dikembangkan dengan melakukan analisis vegetasi guna mengetahui secara kuantitatif populasi akar kuning pada luasan tertentu, pola sebaran serta asosiasi akar kuning.

\section{Pengukuran dan pengambilan data}

Data primer yang dikumpulkan dalam penelitian ini adalah berupa data vegetasi yang dikumpulkan dengan teknik analisis vegetasi. Teknik analisis vegetasi ditujukan untuk menentukan struktur dan komposisi jenis dari suatu tegakan hutan. Teknik analisis vegetasi diterapkan pada jalur-jalur pengamatan dengan lebar $10 \mathrm{~m}$ dan panjang $1 \mathrm{~km}$, yang dibagi ke dalam beberapa sub petak contoh untuk analisis vegetasi tumbuhan F. tinctoria tingkat semai dan pancang.

Pengukuran vegetasi yang dilakukan di dalam petak pengamatan berukuran $2 \mathrm{~m}$ x 2 $\mathrm{m}$ tingkat semai dengan tinggi $<1,5 \mathrm{~m}$ dan petak $5 \mathrm{~m} \times 5 \mathrm{~m}$ tingkat pancang dengan tinggi $\geq 1,5 \mathrm{~m}$ serta pengukuran diameter batang setinggi dada $(\mathrm{dbh}) \leq 10 \mathrm{~cm}$. Semua vegetasi $(\mathrm{dbh} \leq 10 \mathrm{~cm})$ diukur dbh-nya, dicatat, dan diidentifikasi jenisnya, sebanyak 80 plot bersarang di dalam plot. Jenis-jenis yang tidak teridentifikasi di lapangan, dilakukan pengumpulan specimen voucher untuk diidentifikasi di Laboratorium Herbarium Botani, Pusat Penelitian dan Pengembangan Hutan, Bogor, untuk diidentifikasi lebih lanjut. 


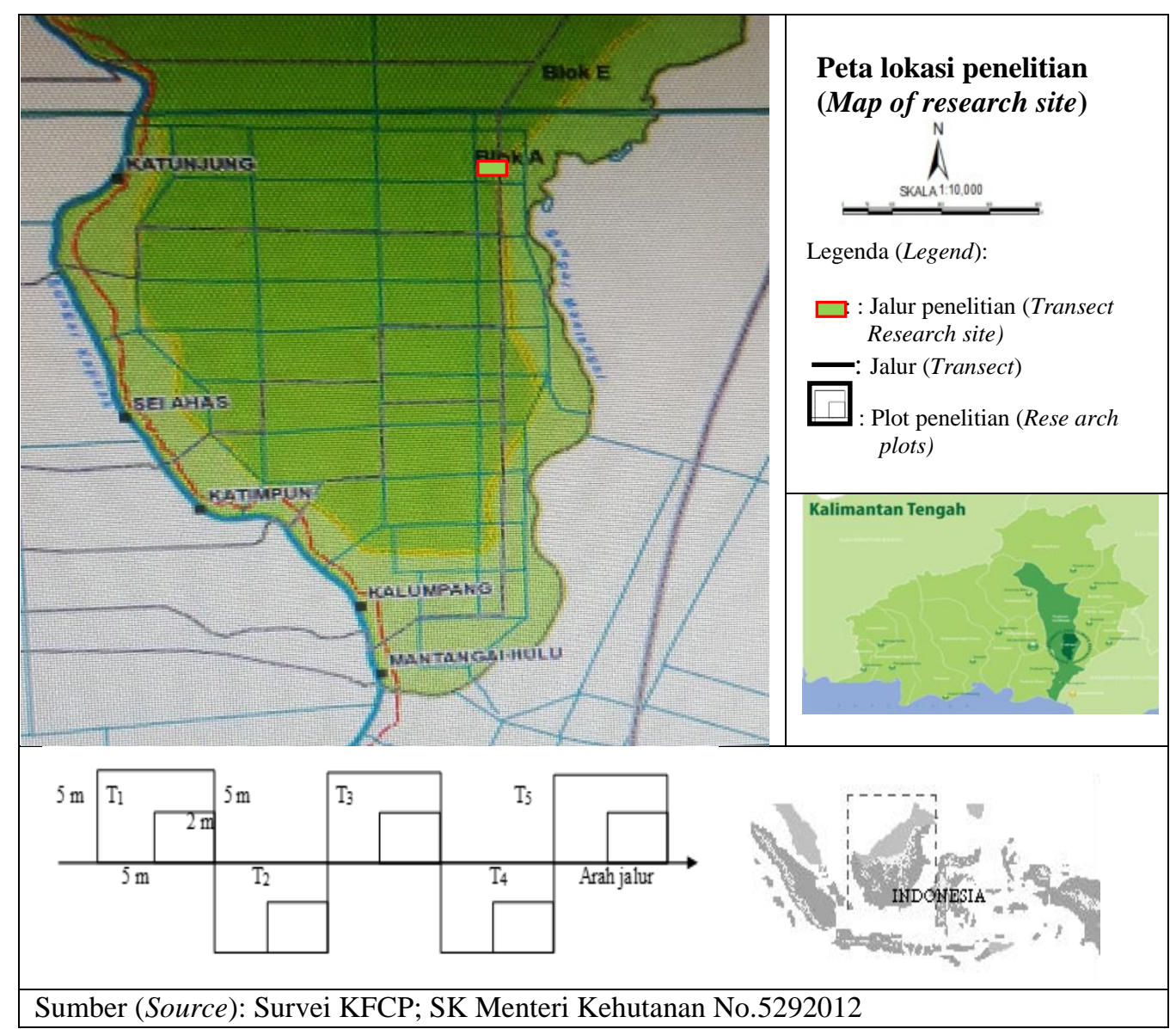

Gambar (Figure) 1. Lokasi penelitian di hutan Blok Release, Kalimantan Tengah (Study location in the Block Release forest, Central Kalimantan)

\section{Analisis Data}

\section{Indeks Nilai Penting (INP)}

Indeks Nilai Penting dalam penelitian ini adalah menghitung kerapatan (densitas) dan frekuensi. Kerapatan adalah jumlah individu F. tinctoria per satuan luas. Kerapatan dihitung dengan menggunakan pendekatan menurut (Mueller-Dombois, \& Ellerberg, 1974).

- Kerapatan Jenis $(\mathrm{K})=$ Jumlah individu suatu jenis dibagi luas plot pengamatan

- Kerapatan Relatif $(\mathrm{KR})=($ Kerapatan suatu jenis dibagi kerapatan seluruh jenis) $\times 100 \%$

- Frekuensi Jenis $(\mathrm{F})=$ Jumlah plot ditemukannya suatu jenis dibagi jumlah total plot pengamatan

- Frekuensi Relatif $(\mathrm{FR})=$ (Frekuensi suatu jenis dibagi frekuensi seluruh jenis) $\times 100 \%$
- Dominansi Jenis (D) = Luas bidang dasar suatu jenis dibagi luas plot pengamatan

- Dominansi Relatif $(\mathrm{DR})=($ Dominasi suatu jenis dibagi dominasi seluruh jenis) $\mathrm{x} 100 \%$

Luas bidang dasar (LBD) digunakan untuk menghitung dominansi suatu jenis diperoleh dengan rumus sebagai berikut:

$L B D=\frac{1}{4} \pi *\left(\frac{D}{100}\right)^{2}$

Dimana: $\pi=3,14$ dan $\mathrm{D}=$ Diameter $(\mathrm{cm})$

Selanjutnya dihitung nilai Indeks Nilai Penting (INP) untuk mengetahui jenis dan tingkat tumbuhan yang dominan dengan rumus sebagai berikut: 
- Semai : $\mathrm{INP}=\mathrm{KR}+\mathrm{FR}$

- Pancang : INP $=\mathrm{KR}+\mathrm{FR}+\mathrm{DR}$

\section{Indeks asosiasi}

Indeks asosiasi digunakan untuk mengetahui hubungan antara F. tinctoria dengan jenis tumbuhan lain penyusun utama yang mendominasi di lokasi penelitian. Hasil perhitungan asosiasi dari spesies-spesies tumbuhan yang memiliki Indeks Nilai Penting $\geq 10 \%$ disajikan dalam bentuk diagram matriks. Selanjutnya hasil ini diuji dengan Indeks Ochiai (Ludwig, \& Reynolds, 1988):

$$
\mathrm{Oi}=\frac{\mathrm{a}}{(\sqrt{a}+b)(\sqrt{a}+c)}
$$

$$
\begin{aligned}
\begin{array}{l}
\text { Dimana } \\
\text { Oi }=
\end{array} & \text { Indeks Ochiai } \\
\mathrm{a}= & \text { Jumlah plot ditemukannya } \\
& \text { kedua jenis a dan } \mathrm{b} \text { (jenis } \\
& \text { A dan B hadir) } \\
\mathrm{b}= & \text { Jumlah plot ditemukannya } \\
& \text { jenis a dan c (jenis A } \\
& \text { hadir, B tidak hadir) } \\
\mathrm{c}= & \text { Jumlah plot ditemukannya } \\
& \text { jenis } \mathrm{b} \text { (jenis A tidak hadir, } \\
& \text { B hadir) }
\end{aligned}
$$

Nilai asosiasi terjadi pada selang nilai 0 (nol) sampai 1 (satu). Hubungan asosiasi akan semakin kuat atau maksimum, apabila hubungannya semakin mendekati nilai 1 . Sebaliknya semakin mendekati nilai 0 , maka asosiasi akan semakin minimum bahkan tidak ada hubungan.

\section{Pola persebaran akar kuning (F. tinctoria)}

Seluruh tumbuhan di hutan alam mempunyai tiga pola persebaran yakni persebaran acak, seragam dan mengelompok. Pola persebaran demikian erat hubungannya dengan kondisi lingkungan. Untuk mengetahui pola sebaran tumbuhan akar kuning (F. tinctoria), menggunakan Indeks Morishita (Id) yang terstandar (Standardized
Morishita's index) (Krebs,1989). Indeks tersebut dihitung dengan persamaan berikut:

$$
I d=n \frac{\sum x^{2}-\sum x}{\left(\sum x\right)^{2}-\sum x}
$$

$$
\begin{aligned}
& \text { Dimana : Id = Indeks sebaran } \\
& \text { Morishita petak } \\
& \mathrm{N}=\text { Jumlah petak } \\
& \sum \mathrm{x}=\text { Jumlah individu } \\
& \text { suatu spesies setiap } \\
& \text { petak pengamatan } \\
& \left(\sum \mathrm{x}\right)^{2}=\text { Jumlah total } \\
& \text { individu yang } \\
& \text { dikuadratkan }
\end{aligned}
$$

Jika: Id $<1$, Pola persebaran jenis individu bersifat teratur atau seragam

Id $=1$, Pola persebaran jenis individu bersifat acak

Id $>1$, Pola persebaran jenis individu bersifat mengelompok

Selanjutnya dilakukan standarisasi Indeks Morishita (Id) dengan rumus (Krebs,1989) sebagai berikut:

a) Menentukan Indeks Seragam (Uniform Indeks $=\mathrm{Mu}$ ) dan Indeks Kelompok (Clumped Indeks $=\mathrm{Mc}$ ) dengan persamaan sebagai berikut:

$$
\begin{aligned}
& \mathrm{Mu}=\frac{\chi_{0,975}^{2}-n+\sum x_{i}}{\left(\sum x_{i}\right)-1} . \\
& \mathrm{Mc}=\frac{\chi_{0,025}^{2}-n+\sum x_{i}}{\left(\sum x_{i}\right)-1} .
\end{aligned}
$$

Dimana:

$\mathrm{Mu} \quad=$ Indeks Morishita untuk pola sebaran seragam

Nilai Chi-square tabel

$\mathrm{X}^{2} 0,975=$ Dengan derajad bebas $\mathrm{n}-1$ dan selang kepercayaan $97,5 \%$

Mc = Indeks Morishita untuk pola sebaran

$\mathrm{X}^{2} 0,025=$ Mengelompok 
Nilai Chi-square tabel dengan derajad bebas n-1 dan selang kepercayaan $2,5 \%$

b) Menghitung Ip dengan menentukan persamaan yang sesuai dengan hasil perhitungan $\mathrm{Id}, \mathrm{Mu}$ dan $\mathrm{Mc}$ dengan ketentuan berikut:

$$
I p=0,5+0,5\left(\frac{I d-M c}{n-M c}\right) ; j \mathrm{jika} \text { Id } \geq \mathrm{Mc}>1
$$

$I P=0,5\left(\frac{I d-1}{M c-1}\right) ;$ jika Mc $>$ Id $\geq 1$

$$
I p=-0,5\left(\frac{I d-1}{M u-1}\right) ; j \text { ika } 1>\mathrm{Id}>\mathrm{Mu}
$$

$I p=-0,5+0,5\left(\frac{I d-M u}{M u}\right) ;$ jika $1>M u>I d$

Indeks dispersi Morishita yang telah distandarisasi (Ip) berkisar antara -1 sampai 1, dengan batas kepercayaan $95 \%$ pada 0,5 dan -0,5. Pola acak (random) memberikan nilai Ip $=0$, pola mengelompok (clumped) jika Ip > 0, dan pola yang seragam (uniform) jika Ip < 0 (Krebs, 1989).

\section{HASIL DAN PEMBAHASAN}

\section{A. Hasil}

\section{Populasi tumbuhan F. Tinctoria}

Hasil pengamatan di lapangan, tumbuhan F. tinctoria merupakan tumbuhan berhabitus liana berkayu, memanjat, termasuk famili Menispermaceae, yang tingginya antara 20-40 $\mathrm{ml}$ batang membulat, diameter batang antara $2-7 \mathrm{~cm}$, kayu berwarna kuning cerah; daun tunggal, tersusun spiral, bentuk daun membulat atau ellip, $\quad 10-25 \mathrm{~cm} \times 5-14 \mathrm{~cm}$, pangkal membulat atau tumpul, tepi rata, ujung daun luncip, bertulang daun primer 3 dari pangkal menonjol di permukaan bawah, tulang daun sekunder 2-4 di kedua sisi tulang daun primer, tulang daun tersier berbentuk, seperti jalal tangkai daun ramping panjang $4-13 \mathrm{~cm}$, membengkak di kedua ujungnya, bila kering tangkai kehitaman. Buah bentuk membulat telur atau menjorong pendek, tidak berbulu, buah masak warna oranye kekuningan, terdiri dari tiga biji, endokarps panjang 2-3 $\mathrm{mm}$, berlekuk, kotiledon memanjang dan melengkung.

Hasil analisis plot pengamatan yang letaknya berselang-seling pada dua jalur untuk masing-masing tingkat pertumbuhan adalah:

1. Semai (seedlings) dengan ukuran plot 2 m x $2 \mathrm{~m}$, sebanyak 80 plot seluas 0,032 ha.

2. Pancang (saplings) dengan ukuran plot 5 $\mathrm{m} \times 5 \mathrm{~m}$, sebanyak 80 plot seluas 0,2 ha.

Jalur I dan Jalur II ditemukan berbagai jumlah individu, spesies, genera, dan famili tumbuhan pada tingkat semai dan pancang.

\section{Potensi akar kuning (F. tinctoria)}

Salah satu indikator yang menunjukkan potensi suatu jenis adalah dengan nilai kerapatannya. Potensi F. tinctoria tingkat semai pada jalur II lebih besar dengan nilai kerapatan 625 individu/ha dan tingkat pancang sebesar 70 individu/ha, bila dibandingkan dengan jalur I (Gambar 3).

Berdasarkan hasil analisis tegakan F. tinctoria menghasilkan vegetasi tingkat semai yang cukup banyak sebagai penyusun hutan alam dibanding dengan vegetasi tingkat pancang. Oleh karena itu, untuk mengetahui populasi F. tinctoria di lokasi penelitian dilakukan dengan pendekatan pengukuran luas bidang dasar (Lampiran 2 dan Lampiran 4). Hasil perhitungan populasi tumbuhan pada habitat F. tinctoria disajikan pada Tabel 2. 

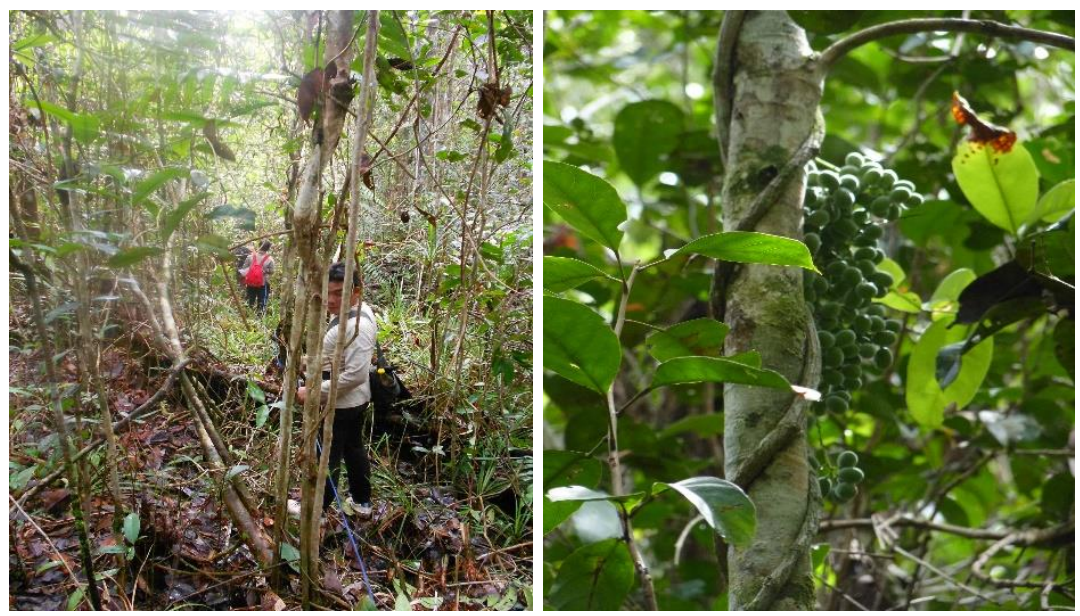

Gambar (Figure) 2. Kondisi tempat tumbuh habitus F. tinctoria berbuah di lokasi penelitian (The habitat condition of $\underline{\mathrm{F}}$. tinctoria fruiting in the study site)

Tabel (Table) 1. Jumlah individu, genera, dan famili pada hutan rawa gambut jalur I dan jalur II untuk tingkat semai dan pancang (Number of individuals, species, genera, and families at transect I and transect II peat swamp forest for seedling and sapling stage)

\begin{tabular}{lcccccc}
\hline & \multicolumn{5}{c}{ Lokasi contoh plot (Location sample plots) } \\
\cline { 2 - 7 } Tingkat (Stage) & \multicolumn{2}{c}{ Jalur (Transect) I } & \multicolumn{3}{c}{ Jalur (Transect) } & II \\
\cline { 2 - 7 } & $\begin{array}{c}\text { Semai } \\
\text { (Seedling) }\end{array}$ & $\begin{array}{c}\text { Pancang } \\
\text { (Sapling) }\end{array}$ & Total & $\begin{array}{c}\text { Semai } \\
\text { (Seedling) }\end{array}$ & $\begin{array}{c}\text { Pancang } \\
\text { (Sapling) }\end{array}$ & Total \\
\hline 1. Individual & 89 & 170 & 259 & 140 & 109 & 249 \\
$\quad$ (Individuals) & 19 & 17 & 28 & 24 & 17 & 34 \\
2. Jenis (Species) & 19 & 15 & 25 & 20 & 17 & 30 \\
3. Genus (Genera) & 19 & 13 & 27 & 19 & 16 & 26 \\
4. Suku (Family) & 17 & & & & & \\
\hline
\end{tabular}

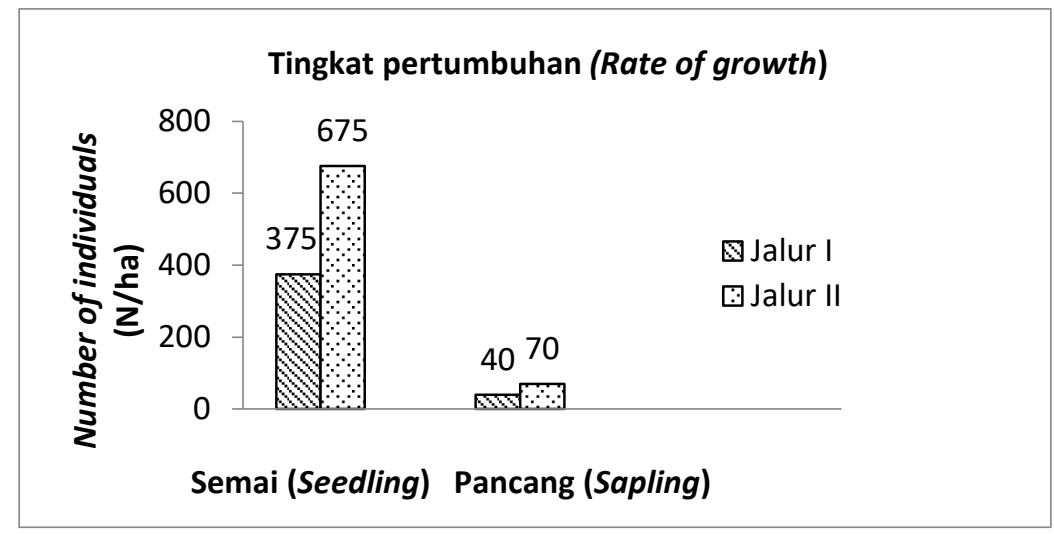

Gambar (Figure) 3. Populasi F. tinctoria per ha pada masing-masing tingkat pertumbuhan pada dua jalur (F.tinctoria population per ha at each growth rate for two transects) 
Tabel (Table) 2. Kerapatan jenis tumbuhan pada habitat F. tinctoria berdasarkan tingkat pertumbuhan (Plant species density in $\mathrm{F}$. tinctoria habitat based on growth rates) (individuals/ha)

\begin{tabular}{|c|c|c|c|c|c|c|}
\hline \multirow{3}{*}{ No } & \multirow{3}{*}{ Spesies (Species) } & \multirow{3}{*}{ Suku (Family) } & \multicolumn{4}{|c|}{ Kerapatan (Density)(N/ha) } \\
\hline & & & \multicolumn{2}{|c|}{ Jalur (Transect) I } & \multicolumn{2}{|c|}{ Jalur (Transect) II } \\
\hline & & & $\begin{array}{l}\text { Semai } \\
\text { (Seedling) }\end{array}$ & $\begin{array}{l}\text { Pancang } \\
\text { (Sapling) }\end{array}$ & $\begin{array}{c}\text { Semai } \\
\text { (Seedling) }\end{array}$ & $\begin{array}{l}\text { Pancang } \\
\text { (Sapling) }\end{array}$ \\
\hline 1 & Acronychia pedunculata (L.) Miq. & Rutaceae & 250 & - & 375 & 100 \\
\hline 2 & Ardisia villosa Roxb. & Myrsinaceae & 375 & 90 & 500 & - \\
\hline 3 & Artabotrys roseus Boerl. & Annonaceae & - & - & 187,5 & - \\
\hline 4 & Asplenium nidus L. & Aspleniaceae & 187,5 & - & - & - \\
\hline 5 & Calophyllum nodusum Vesque & Clusiaceae & - & 150 & 312,5 & - \\
\hline 6 & Calophyllum pulcherrinum Wall. ex Choisy & Clusiaceae & - & - & 312,5 & 80 \\
\hline 7 & Calophyllum sclerophyllum Vesque & Clusiaceae & 375 & - & - & - \\
\hline 8 & Campnosperma auriculatum (Blume) Hk.f. & Anacardiaceae & - & 130 & - & - \\
\hline 9 & Carex baccans Nees & Cyperaceae & 687,5 & - & 437,5 & - \\
\hline 10 & Coleus amboinicus Lour. & Lamiaceae & 562,5 & - & 500 & - \\
\hline 11 & Cryptocarya zollingeriana Miq. & Lauraceae & 250 & 60 & - & - \\
\hline 12 & Dacryodes costata (A.W.Benn.) H.J.Lam & Burseraceae & - & 40 & - & - \\
\hline 13 & Dactylocladus stenostachys Oliv. & Crypteroniaceae. & 125 & - & - & - \\
\hline 14 & Diospyros bantamensis K.et V. & Ebenaceae & 187,5 & - & - & 30 \\
\hline 15 & Fibraurea tinctoria Lour. & Menispermaceae & 375 & 40 & 625 & 70 \\
\hline 16 & Ficus indica $\mathrm{L}$. & Moraceae & 250 & - & - & - \\
\hline 17 & Ficus parietalis Blume & Moraceae & - & - & - & 50 \\
\hline 18 & Freycinetia angustifolia Blume & Pandanaceae & 500 & 80 & 500 & - \\
\hline 19 & Freycinetia borneensis Martelli & Pandanaceae & - & - & 312,5 & - \\
\hline 20 & $\begin{array}{l}\text { Ganua motleyana (de Vriese) Pierre ex. } \\
\text { Dubard. }\end{array}$ & Sapotaceae & 187,5 & - & - & - \\
\hline 21 & Horsfieldia irya (Blume) Warb. & Myristicaceae & - & - & - & 50 \\
\hline 22 & Ilex bogoriensis Kds. & Aquifoliaceae & - & 100 & & 20 \\
\hline 23 & Korthalsia rigida Beccari & Arecaceae & - & - & 375 & 110 \\
\hline 24 & $\begin{array}{l}\text { Macaranga gigantea (Reichb.f. \& Zoll.) } \\
\text { Müll.Arg. }\end{array}$ & Euphorbiaceae & - & - & - & 130 \\
\hline 25 & Mangifera similis Blume & Anacardiaceae & - & 140 & - & 20 \\
\hline 26 & Mimosa pigra $\mathrm{L}$. & Fabaceae & - & - & 312,5 & - \\
\hline 27 & Murraya paniculata Jack. & Rutaceae & - & - & - & 60 \\
\hline 28 & $\begin{array}{l}\text { Neoscortechinia kingii (Hook.f.) Pax \& } \\
\text { K.Hoffm.] }\end{array}$ & Euphorbiaceae & - & - & 250 & - \\
\hline 29 & Nepenthes gracilis Korth. & Nephentaceae & - & - & 312,5 & - \\
\hline 30 & Nepenthes mirabilis(Lour.) Druce & Nephentaceae & - & - & 625 & - \\
\hline 31 & Nephelium juglanifolium Blume & Sapindaceae & 312,5 & 110 & 437,5 & - \\
\hline 32 & Phalaenopsis amabilis Blume & Orchidaceae & 187,5 & - & - & - \\
\hline 33 & Palaquium cochlearia H.J.L & Sapotaceae & - & 110 & - & - \\
\hline 34 & Parastemon urophyllum A.DC. & Rosaceae & - & 50 & - & 40 \\
\hline 35 & Pittosporium pentandrum (Blanco) Merr. & Pittosporaceae & - & - & - & 20 \\
\hline 36 & Shorea balangeran Burck & Dipterocarpaceae & 437,5 & 180 & 750 & 90 \\
\hline 37 & Spathoglottis plicata Blume & Orchidaceae & - & - & 375 & - \\
\hline 38 & Stemonurus scorpioides Beccari & Icacinaceae & - & - & 187,5 & 40 \\
\hline 39 & Stenochlaena palustris (Burm F) Bedd & Clusiaceae & 125 & - & 562,5 & - \\
\hline
\end{tabular}


Potensi Akar Kuning (Fibraurea tinctoria Lour.) di Hutan

Rawa-Gambut, Kabupaten Kapuas, Provinsi Kalimantan Tengah

Titi Kalima

Lanjutan (To be continue)

\begin{tabular}{|c|c|c|c|c|c|c|}
\hline \multirow{3}{*}{ No } & \multirow{3}{*}{ Spesies (Species) } & \multirow{3}{*}{ Suku (Family) } & \multicolumn{4}{|c|}{ Kerapatan (Density)(N/ha) } \\
\hline & & & \multicolumn{2}{|c|}{ Jalur (Transect) I } & \multicolumn{2}{|c|}{ Jalur (Transect) II } \\
\hline & & & $\begin{array}{c}\text { Semai } \\
\text { (Seedling) }\end{array}$ & $\begin{array}{l}\text { Pancang } \\
\text { (Sapling) }\end{array}$ & $\begin{array}{c}\text { Semai } \\
\text { (Seedling) }\end{array}$ & $\begin{array}{l}\text { Pancang } \\
\text { (Sapling) }\end{array}$ \\
\hline 40 & Syzygium garcinaefolia King & Myrtaceae & - & - & 125 & 120 \\
\hline 41 & Syzygium glabratum (DC.) Veldkamp & Myrtaceae & 62,5 & 60 & 125 & - \\
\hline 42 & Syzygium laxiflora K.et V. & Myrtaceae & - & 90 & - & - \\
\hline 43 & Syzygium spicata Lamk. & Myrtaceae & - & 100 & - & - \\
\hline 44 & Taenitis blechnoides $\mathrm{Sw}$. & Pteridaceae & - & - & 187,5 & - \\
\hline 45 & Tristaniopsis obovata Willson & Myrtaceae & 125 & 170 & - & - \\
\hline 46 & Uncaria gambir (W.Hunter) Roxb. & Rubiaceae & - & - & 62,5 & - \\
\hline 47 & Xanthophyllum ellipticum. Korth. ex Miq. & Polygalaceae & - & - & - & 60 \\
\hline & Jumlah jenis (Number of spesies) & & 19 & 17 & 24 & 17 \\
\hline & Jumlah kerapatan (Number of Density) N/h & & $5.562,5$ & 1.700 & 8.750 & 1.090 \\
\hline
\end{tabular}

Tabel (Table) 3. Indeks Nilai Penting pada lokasi penelitian (Importance Value Index at the research site)

\begin{tabular}{|c|c|c|c|c|c|c|}
\hline \multirow{2}{*}{ No } & \multirow{2}{*}{ Spesies (Species) } & \multirow{2}{*}{ Suku (Family) } & \multicolumn{4}{|c|}{ INP (Importance Value Index)(\%) } \\
\hline & & & $\begin{array}{l}\text { Semai } \\
\text { (Seedling) }\end{array}$ & $\begin{array}{l}\text { Pancang } \\
\text { (Sapling) }\end{array}$ & $\begin{array}{c}\text { Semai } \\
\text { (Seedling) }\end{array}$ & $\begin{array}{l}\text { Pancang } \\
\text { (Sapling) }\end{array}$ \\
\hline 1 & $\begin{array}{l}\text { Macaranga gigantea (Reichb.f. \& Zoll.) } \\
\text { Müll.Arg. }\end{array}$ & Euphorbiac ae & - & - & & 33,03 \\
\hline 3 & Carex baccans Nees & Cyperaceae & 19,86 & - & 9,26 & - \\
\hline 4 & Freycinetia angustifolia Blume & Pandanaceae & 18,99 & 15,26 & 12,10 & - \\
\hline 5 & Syzygium garcinaefolia King & Myrtaceae & - & - & 3,56 & 31,87 \\
\hline 6 & Shorea balangeran Burck & Dipterocarpaceae & 17,87 & 29,57 & 14,95 & 30,97 \\
\hline 10 & $\begin{array}{l}\text { Xanthophyllum ellipticum Korth. ex } \\
\text { Miq. }\end{array}$ & Polygalaceae & - & - & - & $18,97-$ \\
\hline 11 & Murraya paniculata Jack. & Rutaceae & & & & 16,97 \\
\hline 12 & Calophyllum nodusum Vesque & Clusiaceae & & 27,73 & 7,83 & \\
\hline 13 & Syzygium laxiflora K.et V. & Myrtaceae & & 25,70 & & \\
\hline 14 & $\begin{array}{l}\text { Campnosperma auriculatum (Blume) } \\
\text { Hk.f. }\end{array}$ & Anacardiaceae & & 23,03 & & \\
\hline 15 & Mangifera similis Blume & Anacardiaceae & & 20,58 & & 5,85 \\
\hline 16 & Palaquium cochlearia H.J.L & Sapotaceae & & 18,17 & & \\
\hline 22 & Syzygium spicata Lamk. & Myrtaceae & 3,62 & 16,89 & & \\
\hline 23 & Ficus indica $\mathrm{L}$. & Moraceae & 9,49 & & & \\
\hline 24 & Ardisia villosa Roxb. & Myrsinaceae & 9,24 & 16,11 & 9,97 & \\
\hline 25 & Calophyllum sclerophyllum Vesque & Clusiaceae & 9,24 & & & \\
\hline 26 & Asplenium nidus $\mathrm{L}$. & Aspleniaceae & 8,37 & & & \\
\hline
\end{tabular}


Lanjutan (To be continue)

\begin{tabular}{|c|c|c|c|c|c|c|}
\hline \multirow{3}{*}{ No } & \multirow{3}{*}{ Spesies (Species) } & \multirow{3}{*}{ Suku (Family) } & \multicolumn{4}{|c|}{ INP (Importance Value Index) $(\%)$} \\
\hline & & & \multicolumn{2}{|c|}{ Jalur (Transect) I } & \multicolumn{2}{|c|}{ Jalur (Transect) II } \\
\hline & & & $\begin{array}{l}\text { Semai } \\
\text { (Seedling) }\end{array}$ & $\begin{array}{l}\text { Pancang } \\
\text { (Sapling) }\end{array}$ & $\begin{array}{c}\text { Semai } \\
\text { (Seedling) }\end{array}$ & $\begin{array}{l}\text { Pancang } \\
\text { (Sapling) }\end{array}$ \\
\hline 27 & $\begin{array}{l}\text { Ganua motleyana (de Vriese) Pierre ex. } \\
\text { Dubard. }\end{array}$ & Sapotaceae & 8,37 & - & - & - \\
\hline 28 & Dactylocladus stenostachys Oliv. & Crypteroniaceae. & 7,25 & - & - & - \\
\hline 29 & Phalaenopsis amabilis Blume & Orchidaceae & 5,87 & - & - & - \\
\hline 30 & Ilex bogoriensis Kds. & Aquifoliaceae & - & 15,52 & - & 7,10 \\
\hline 31 & Parastemon urophyllum A.DC. & Rosaceae & - & 11,12 & - & 13,43 \\
\hline 32 & Nepenthes mirabilis(Lour.) Druce & Nephentaceae & - & - & 13,53 & - \\
\hline 33 & Stenochlaena palustris (Burm F) Bedd. & Aspleniaceae & 4,75 & - & 10,68 & 13,09 \\
\hline 34 & Ficus parietalis Blume & Moraceae & - & - & - & 13,41 \\
\hline 35 & Horsfieldia irya (Blume) Warb. & Myristicaceae & - & - & - & 11,93 \\
\hline 36 & Pittosporium pentandrum (Blanco) Merr. & Pittosporaceae & - & - & - & 6,98 \\
\hline 37 & Nepenthes gracilis Korth. & Nephentaceae & - & - & 9,95 & - \\
\hline 38 & Freycinetia borneensis Martelli & Pandanaceae & - & - & 7,83 & - \\
\hline 39 & Mimosa pigra $\mathrm{L}$. & Fabaceae & - & - & 7,83 & - \\
\hline 40 & $\begin{array}{l}\text { Neoscortechinia kingii (Hook.f.) Pax \& } \\
\text { K.Hoffm. }\end{array}$ & Euphorbiaceae & - & - & 7,11 & - \\
\hline 41 & Spathoglottis plicata Blume & Orchidaceae & - & - & 6,41 & - \\
\hline 42 & Artabotrys roseus Boerl. & Annonaceae & - & - & 4,27 & - \\
\hline 43 & Stemonurus scorpioides Beccari & Icacinaceae & - & - & 4,27 & - \\
\hline 44 & Taenitis blechnoides $\mathrm{Sw}$. & Pteridaceae & - & - & 4,27 & - \\
\hline 45 & Syzygium glabratum (DC.) Veldkamp & Myrtaceae & - & 7,89 & 3,56 & - \\
\hline 46 & Uncaria gambir (W.Hunter) Roxb. & Rubiaceae & - & - & 2,84 & - \\
\hline \multirow[t]{2}{*}{47} & Dacryodes costata (A.W.Benn.) H.J.Lam & Burseraceae & - & 6,57 & - & \\
\hline & Jumlah spesies (Number of species) & & 19 & 17 & 24 & 17 \\
\hline
\end{tabular}

Tabel (Table) 4. Nilai Indeks Asosiasi F. tinctoria dengan tumbuhan lain pada lokasi penelitian (The index value of the $\mathrm{F}$. tinctoria association with other plants at the study location)

\begin{tabular}{|c|c|c|c|c|c|c|}
\hline No & Jalur (Transect) & $\begin{array}{l}\text { INP } \\
(I V I)\end{array}$ & $\mathrm{a}$ & $a+b$ & $\mathrm{a}+\mathrm{c}$ & OI \\
\hline & I. Semai (Seedling) & & & & & \\
\hline 1 & Carex baccans Nees & 19,86 & 6 & 30 & 30 & 0,20 \\
\hline 2 & Freycinetia angustifolia Blume & 18,99 & 7 & 32 & 31 & 0,23 \\
\hline 3 & Shorea balangeran Burck & 17,87 & 7 & 32 & 31 & 0,23 \\
\hline 4 & Coleus amboinicus Lour. & 15,11 & 5 & 28 & 30 & 0,17 \\
\hline 5 & Cryptocarya zollingeriana Miq. & 11,99 & 6 & 30 & 30 & 0,20 \\
\hline 6 & Diospyros bantamensis K.et V. & 10,87 & 6 & 30 & 30 & 0,20 \\
\hline \multirow[t]{2}{*}{7} & Nephelium juglanifolium Blume & 10,62 & 5 & 28 & 30 & 0,17 \\
\hline & Pancang (Sapling) & & & & & \\
\hline 1 & $\begin{array}{l}\text { Tristaniopsis obovata (R. Br.) Peter G. Wilson \& } \\
\text { J.T. Waterh. }\end{array}$ & 30,06 & 3 & 41 & 36 & 0,48 \\
\hline 2 & Shorea balangeran Burck & 29,57 & 4 & 44 & 36 & 0,63 \\
\hline 3 & Calophyllum nodusum Vesque & 27,73 & 3 & 41 & 36 & 0,48 \\
\hline 4 & Syzygium laxiflora K.et V. & 25,70 & 2 & 40 & 36 & 0,32 \\
\hline 5 & Campnosperma auriculatum (Blume) Hk.f. & 23,03 & 3 & 41 & 36 & 0,48 \\
\hline 6 & Mangifera similis Blume & 20,58 & 4 & 44 & 36 & 0,63 \\
\hline 7 & Palaquium cochlearia H.J.L & 18,17 & 2 & 40 & 36 & 0,32 \\
\hline 8 & Nephelium juglanifolium Blume & 17,61 & 3 & 41 & 36 & 0,48 \\
\hline 9 & Syzygium spicata Lamk. & 16,89 & 2 & 40 & 36 & 0,32 \\
\hline 10 & Ardisia villosa Roxb. & 16,11 & 3 & 41 & 36 & 0,48 \\
\hline
\end{tabular}


Lanjutan (To be continue)

\begin{tabular}{|c|c|c|c|c|c|c|}
\hline No & Jalur (Transect) & $\begin{array}{c}\text { INP } \\
\text { (IVI) }\end{array}$ & $\mathrm{a}$ & $a+b$ & $a+c$ & OI \\
\hline 11 & IIex bogoriensis $\mathrm{Kds}$. & 15,52 & 3 & 41 & 36 & 0,48 \\
\hline 12 & Freycinetia angustifolia Blume & 15,26 & 2 & 40 & 36 & 0,32 \\
\hline \multirow[t]{2}{*}{13} & Parastemon urophyllum A.DC. & 11,12 & 2 & 40 & 36 & 0,32 \\
\hline & II. Semai (Seedling) & & & & & \\
\hline 1 & Shorea balangeran Burck & 14,95 & 6 & 23 & 23 & 0,26 \\
\hline 2 & Nepenthes mirabilis(Lour.) Druce & 13,53 & 6 & 23 & 23 & 0,26 \\
\hline 3 & Coleus amboinicus Lour. & 12,10 & 6 & 23 & 23 & 0,26 \\
\hline 4 & Freycinetia angustifolia Blume & 12,10 & 6 & 23 & 23 & 0,26 \\
\hline \multirow[t]{2}{*}{5} & Stenochlaena palustris (Burm F) Bedd & 10,68 & 5 & 21 & 23 & 0,23 \\
\hline & Pancang (Sapling) & & & & & \\
\hline 1 & Macaranga gigantea (Reichb.f. \& Zoll.) Müll.Arg. & 33,03 & 7 & 44 & 42 & 0,16 \\
\hline 2 & Syzygium garcinaefolia King & 31,87 & 6 & 42 & 42 & 0,15 \\
\hline 3 & Shorea balangeran Burck & 30,97 & 7 & 44 & 42 & 0,16 \\
\hline 4 & Acronychia pedunculata (L.) Miq. & 27,89 & 6 & 42 & 42 & 0,15 \\
\hline 5 & Calophyllum pulcherrinum Wall. ex Choisy & 22,42 & 6 & 42 & 42 & 0,15 \\
\hline 6 & Korthalsia rigida Beccari & 19,03 & 6 & 42 & 42 & 0,15 \\
\hline 7 & Xanthophyllum ellipticum. Korth. ex Miq. & 18,97 & 6 & 42 & 42 & 0,15 \\
\hline 8 & Murraya paniculata Jack. & 16,97 & 5 & 40 & 42 & 0,12 \\
\hline 9 & Parastemon urophyllum A.DC. & 13,43 & 5 & 40 & 42 & 0,12 \\
\hline 10 & Ficus parietalis Blume & 13,41 & 5 & 40 & 42 & 0,12 \\
\hline 11 & Stemonurus scorpioides Beccari & 13,09 & 5 & 40 & 42 & 0,12 \\
\hline 12 & Horsfieldia irya (Blume) Warb. & 11,93 & 5 & 40 & 42 & 0,12 \\
\hline
\end{tabular}

\section{Dominansi akar kuning (F.tinctoria)}

Dominansi jenis dihitung melalui Indeks Nilai Penting (INP), yang merupakan jumlah dari kerapatan relatif, frekuensi relatif dan dominansi relatif untuk tiap tingkat pertumbuhan (semai dan pancang) di setiap petak pengamatan. Jenis akar kuning (F. tinctoria) pada jalur I memiliki INP sebesar 14,24\% (tingkat semai) dan $8,89 \%$ (tingkat pancang). Pada jalur II tingkat semai memiliki INP 15,53\% dan pancang dengan INP 18,43\%. Tumbuhtumbuhan yang mendominasi tingkat semai pada jalur I berturut-turut adalah $\mathrm{C}$. baccans dengan Indeks Nilai Penting (INP) sebesar 19,86\%, F. angustifolia (INP = $18,99 \%$ ), dan S. balangeran (INP = 17,87\%) (Tabel 3) (Lampiran 1). Pada tingkat pancang didominasi oleh $T$. obovata $(\mathrm{INP}=30,06 \%), \mathrm{S}$. balangeran $(\mathrm{INP}=$ $29,57 \%)$ dan C. nodusum $(\mathrm{INP}=27,73 \%)$ (Tabel 3.) (Lampiran 2). Selain itu, jenis tumbuhan lain yang mendominasi tingkat semai pada jalur II adalah S. balangeran $(\mathrm{INP}=14,95 \%)$, F. tinctoria $(\mathrm{INP}=$ $13,53 \%)$ dan $N$. mirabilis $(\mathrm{INP}=13,53 \%)$ serta $\mathrm{F}$. angustifolia $(\mathrm{INP}=12,10 \%)$ dan $\mathrm{C}$. amboinicus (INP $=12,10 \%)$ (Tabel 3) (Lampiran 3). Pada tingkat pancang yang mendominasi tumbuhan F. tinctoria adalah M. gigantea $(\mathrm{INP}=33,03 \%), \mathrm{S}$. garcinaefolia (INP $=31,87 \%)$, dan $\mathrm{S}$. balangeran (INP $=30,97 \%)$ (Tabel 3.) (Lampiran 4).

\section{Asosiasi F. tinctoria dengan tumbuhan lain}

Indeks asosiasi digunakan untuk mengetahui keeratan hubungan antara $\mathrm{F}$. tinctoria dengan spesies tumbuhan lain di lokasi penelitian. Hasil perhitungan Indeks asosiasi antara F. tinctoria dengan tumbuhan yang memiliki INP $\geq 10 \%$, ditampilkan pada Tabel 4.

Hasil uji Indeks Ochiai diperoleh akar kuning tidak berasosiasi dengan jenis tumbuhan dominan karena indeks asosiasi sangat rendah dengan $<0,22$ ( 17 jenis semai dan pancang) dan 18 jenis mempunyai indeks asosiasi rendah dengan 0,48-0,23, serta dua jenis yang menunjukkan asosiasi 
tinggi, nilai yang diperoleh $5,41 \%$ (Tabel 6).

\section{Pola persebaran F. tinctoria}

Pola persebaran akar kuning (F. tinctoria), berdasarkan Indeks Morishita (Id) terlihat pada Tabel 5.

Berdasarkan Tabel 5 di atas dapat diketahui bahwa pola sebaran semai dan pancang akar kuning di lokasi penelitian adalah seragam atau teratur karena hasil perhitungan Indeks Morishita menunjukkan kurang dari 1.

\section{B. Pembahasan}

Tingkat kerapatan tumbuhan F. tinctoria tingkat semai pada lokasi penelitian akan berpengaruh kepada perkembangbiakannya. Tumbuhan $\mathrm{F}$. tinctoria dalam tingkat semai tentu belum mampu bereproduksi dengan baik, sehingga produksi benih $F$. tinctoria akan terganggu dan polinator tertentu akan mencari bunga tumbuhan pengganti untuk kelangsungan hidupnya. Kelimpahan populasi akar kuning (F. tinctoria) yang tinggi mendominasi tingkat pertumbuhan semai baik jalur I (375batang/ha) maupun jalur II (625 batang/ha). Sesuai hasil penelitian Susila, Setiawan, \& Hidayatullah, M. (2019) bahwa kelimpahan jenis tumbuhan merambat (ketak/Lygodium circinnatum di KPHL Rinjani Barat, hanya tersedia sulur yang siap dipanen rata-rata 3 batang/rumpun (diameter ruas batang pertama $\geq 3 \mathrm{~mm}$ ). Selanjutnya dominansi diikuti tingkat pancang 40 batang/ha (Jalur I) dan 70 batang/ha (Jalur II). Pernyataan ini sesuai hasil penelitian Karmilasanti, \& Fajri, (2020), struktur tegakan horizontal di hutan sekunder menunjukkan bahwa semakin besar kelas diameter, maka semakin berkurang jumlah pohonnya. Ini menunjukkan proses regenerasi alami $\mathrm{F}$. tinctoria yang cukup baik, walaupun lambat, dapat memulihkan kondisi vegetasi menyerupai hutan sekunder. Oleh karena itu, semai-semai tersebut dapat dikelola guna untuk konservasi in situ sebagai tegakan induk atau penyedia benih. Regenerasi hutan secara alami sangat tergantung pada ketersediaan benih di alam, yang berasal dari tegakan induk F. tinctoria disekitarnya ketika terjadi persebaran benih (seed dispersal) dari buah yang jatuh atau melalui rimpang F. tinctoria, sehingga diperlukan upaya penyelamatan semai tersebut baik melalui konservasi eks situ maupun in situ di habitat alami.

Berdasarkan eksplorasi tegakan akar kuning (F. tinctoria) pada kelompok hutan Blok Release, Kecamatan Mantangai, Kabupaten Kapuas, Kalimantan Tengah terdapat indikasi adanya populasi atau kerapatan akar kuning (F. tinctoria) tingkat semai ditemukan lebih besar (375 individu/ha, jumlah 6 batang dan 625 individu/ha, jumlah 10 batang) dalam luasan 0,2 ha (Tabel 2). Nilai ini jauh lebih besar dibandingkan dengan hasil penelitian Noorcahyati, Sulandjari, \& Dewi (2016) yang melaporkan bahwa kepadatan akar kuning di kelompok hutan di Desa Sungai Merdeka, Kecamatan Samboja, Kabupaten Kutai Kartanegara, Kalimantan Timur, yaitu 52 individu/ha akar kuning (F. tinctoria) tingkat semai dalam luasan 0,08 ha. Tegakan akar kuning ini merupakan tegakan alam yang telah diidentifikasi menghasilkan populasi benih-benih yang cukup banyak dan potensial digunakan sebagai sumber benih. Hal ini perlu menjadi perhatian pihak pengelola hutan dalam hal ini adalah pemerintah atau pemangku adat untuk penyelamatan akar kuning. 
Tabel (Table) 6. Indeks asosiasi F. tinctoria dengan jenis-jenis tumbuhan dominan di lokasi penelitian (The association index of $\underline{\mathrm{F}}$. tinctoria with dominant plant species in the study location)

\begin{tabular}{cllcc}
\hline No & $\begin{array}{l}\text { Indeks asosiasi } \\
\text { (Association index) }\end{array}$ & $\begin{array}{c}\text { Asosiasi } \\
\text { (Association) }\end{array}$ & $\begin{array}{c}\text { Jumlah kombinasi } \\
\text { Number of combinations) }\end{array}$ & $\begin{array}{c}\text { Persentase } \\
\text { (Percentage) } \%\end{array}$ \\
\hline 1 & $1,00-0,75$ & Sangat tinggi (Very high) & 0 & 0 \\
2 & $0,74-0,49$ & Tinggi (High) & 2 & 5,41 \\
3 & $0,48-0,23$ & Rendah (Low) & 18 & 48,65 \\
4 & $<0,22$ & Sangat rendah (Very low) & 17 & 45,94 \\
\hline & Jumlah (Amount) & & 37 & 100 \\
\hline
\end{tabular}

Tabel (Table) 5. Pola persebaran F. tinctoria pada lokasi penelitian (Distribution pattern of F. tinctoria at the study site)

\begin{tabular}{ccccc}
\hline Jalur (Transect) & Id & $\mathrm{M}_{\mathrm{u}}$ & $\mathrm{Ip}$ & $\begin{array}{c}\text { Pola sebaran } \\
\text { (Distribution pattern) }\end{array}$ \\
\hline I. Semai (Seedling) & $-0,27$ & 0,71 & $-1,14$ & $\begin{array}{l}\text { Seragam atau teratur } \\
\text { (Uniform or regular) } \\
\text { Peragam atau teratur }\end{array}$ \\
II. Semai (Seedling) & $-0,16$ & 0,81 & $-1,08$ & $\begin{array}{l}\text { Seragam atau teratur } \\
\text { (Uniform or regular) }\end{array}$ \\
Pancang (Sapling) & $-0,20$ & 0,76 & $-1,10$ & $\begin{array}{l}\text { Seragam atau teratur } \\
\text { (Uniform or regular) }\end{array}$ \\
\hline
\end{tabular}

Keterangan (Remarks): Id = Indeks Morishita (Morishita index), Mu = Indeks Morishita untuk pola sebaran seragam (Morishita Index for uniform distribution patterns), Ip = Indeks Morishita yang distandarisasi (Standardized Morishita Index)

Namun untuk memenuhi kriteria tegakan benih, jumlah pohon yang disyaratkan Direktorat Jenderal Pengelolaan DAS dan Rehabilitasi Hutan, KLHK untuk dijadikan tegakan benih teridentifikasi (TBI) sekurang - kurangnya terdapat 25 pohon. Ukuran populasi akan memengaruhi reproduksi tumbuhan akar kuning dan mampu memproduksi benih. Informasi ini sangat penting diketahui untuk mengelola suatu populasi tegakan akar kuning yang diperuntukkan untuk sumber benih yang berada pada suatu tegakan alam. Untuk itu, perlu adanya peningkatan dalam hal pembangunan sumber benih terutama jenis-jenis yang potensial, namun belum banyak dikembangkan seperti halnya jenis akar kuning (F. tinctoria). Dalam peraturan Menteri Linfkungan Hidup dan Kehutanan Nomor P.3/MENLHK/SETJEN/KUM.1/1/ 2020 tentang Penyelenggaraan Perbenihan Tanaman Hutan, sumber benih terbagi atas:
(1) Tegakan benih terdidentifikasi, (2) Tegakan benih terseleksi, (3) Areal produksi benih, (4) Tegakan benih provenan, (5) Kebun benih semai, (6) Kebun benih klon, dan (7) Kebun pangkas (Leksono, 2010). Tegakan Benih Teridentifikasi (TBI) merupakan penghasil benih yang ditunjukan untuk jangka pendek. Syarat untuk menunjuk sumber benih ini adalah telah diketahui batas areal dan komposisi jenisnya, namun jalur isolasi belum diperlukan. Tegakan tersebut harus didominasi oleh jenis yang ditunjuk atau diinginkan (F. tinctoria), namun tindakan silvikultur belum dilakukan, seperti penjarangan, stimulasi pembungaan. Jumlah pohon pada tegakan ini minimal berjumlah 25 pohon untuk menjaga keragaman genetik. TBI harus masih produktif, sehingga mampu memproduksi benih dalam jumlah yang cukup dan berkualitas (Leksono, 2010). 
Rendahnya populasi akar kuning tingkat pancang di lokasi penelitian bila dibandingkan dengan tingkat semai (Gambar 2), dapat disebabkan beberapa faktor antara lain pemanenan akar kuning yang dilakukan oleh masyarakat karena permintaan bahan baku obat-obatan yang meningkat. Pemanenan F. tinctoria oleh masyarakat lokal tidak mengindahkan diameter batang akar kuning yang harus dipanen karena belum adanya peraturan atau pedoman dalam memanen akar kuning (Rinaldi, Suryanto, \& Widuri (2017). Selain itu tidak adanya upaya konservasi baik ex situ maupun in situ tumbuhan akar kuning, lambat laun dapat mengancam dan berakibat kepunahan pada tumbuhan akar kuning. Menurut Ordonez, et al. (2014). Bahwa ada banyak faktor yang memengaruhi keanekaragaman jenis flora, yaitu faktor proses alami dan faktor eksternal. Proses alami terjadi akibat adanya propagul dari bank benih, regenerasi alami dari tingkat anakan sampai tingkat pancang sedangkan faktor eksternal terdiri dari aktivitas manusia, seperti kegiatan pemanenan tumbuhan akar kuning (F. tinctoria).

Dilihat komposisi dan struktur vegetasi ketiga tumbuhan yang mendominasi (Tabel 3), memiliki kesempatan mendapatkan ruang hidup lebih luas, sehingga memungkinkan kehidupan lebih banyak individu (kekayaan). Perbedaan komposisi jenis antar komunitas hutan pada lokasi penelitian ini, erat kaitannya dengan keanekaragaman jenis pada masing-masing komunitas hutan. Hal ini disebabkan komposisi jenis yang ditunjukan oleh Indeks Nilai Penting (INP) merupakan penjumlahan dari faktor (nilai) kerapatan (kelimpahan) relatif, frekuensi relatif dan dominasi relatif. INP juga dapat digunakan sebagai parameter penentuan pentingnya suatu jenis prioritas untuk konservasi.

Secara ekonomi vegetasi tumbuhan $\mathrm{C}$. baccans menurut Ghorbani, Langenberger, Feng, \& Sauerborn (2011) dan Roy, \& Giri (2016) berpotensi sebagai bahan baku obat tradisional yang digunakan di India Timur
Laut, dimana tumbuhan ini menghasilkan senyawa bioaktif, untuk mengobati hipertensi, demam, dismenorea, keputihan, chincough, maag, campak dan masalah ginekologis oleh berbagai kelompok etnis di Asia. Selain itu, C. baccans berpotensi sebagai pakan ternak rusa (Garsetiasih, Alikodra, Soekmadi, \& Bismark, 2012), untuk F. angustifolia berpotensi sebagai pakan ternak anoa (Bubalus spp.) (Broto, 2015). Kemudian yang mendominasi tingkat pancang adalah T. obovata (INP = $30,06 \%)$, S. balangeran $(\mathrm{INP}=29,57 \%)$ dan $C$. nodusum $($ INP $=27,73 \%) \quad($ Tabel 3 dan Lampiran 2). Ketiga jenis ini ditemukan juga di Taman Nasional Sebangau, Kalimantan Tengah (Kalima, \& Denny, 2019). Menurut Turjaman, Faulina, Aryanto, Najmulah, Yani, \& Hidayat (2019) menyatakan bahwa T. obovata (pelawan) bersimbiosis dengan fungi ektomikoriza yang menghasilkan buah fungi yang dapat dikonsumsi (edible mushroom) dan bunga pelawan sebagai sumber nektar untuk lebah hutan yang memproduksi madu pahit yang bernilai ekonomi tinggi. Pada jalur II, jenis N. mirabilis $(\mathrm{INP}=15,53 \%)$, S. balangeran $(\mathrm{INP}=14,98 \%)$, dan C. amboinicus $(\mathrm{INP}=$ $12,10 \%$ ) mendominasi tingkat semai (Tabel 3 dan Lampiran 3) dan tingkat pancang oleh jenis M. gigantea (INP $=33,03 \%), \mathrm{S}$. garcinaefolia $(\mathrm{INP}=31,87 \%)$, dan $\mathrm{S}$. balangeran $(\mathrm{INP}=30,97 \%)$ (Tabel 3 dan Lampiran 4). Jenis-jenis yang mendominasi dalam penelitian ini menunjukkan memiliki pertumbuhan untuk kelangsungan hidup terbaik (Tata, \& Pradjadinata, 2016). The IUCN Red List of Threatened Species version 2020 menyatakan bahwa S. balangeran memiliki kategori rentan (Vulnerable), merupakan jenis endemik hutan rawa gambut Kalimantan dan terancam punah (Robiansyah, 2020). N. mirabilis biasa dijumpai di daerah terbuka di lahan basah, tumbuh di tanah podsolik merah atau di tanah berawa, dengan nilai $\mathrm{pH}$ $\mathrm{H}_{2} \mathrm{O}$ dengan kisaran nilai 3,83-4,47 dan $\mathrm{pH}$ $\mathrm{KCl}$ dengan kisaran nilai 3,35-3,64, dan rasio $\mathrm{C} / \mathrm{N}$ adalah 20,52-40,34 (Hidayat, 
Helmanto, Danang, Purnomo, \& Supriyatna, 2018). Hasil penelitian Lestariningsih, \& Setyaningsih (2017) menyatakan bahwa habitat Nepenthes spp. di hutan rawa gambut dengan $\mathrm{pH}$ tanah berkisar antara 4-6,5.

Hasil perhitungan menunjukkan nilai Indeks Morishita < 1 (Tabel 5). Oleh sebab itu, dapat dikatakan bahwa secara keseluruhan jenis tumbuhan akar kuning yang ditemukan di lokasi penelitian memiliki pola persebaran individu bersifat seragam (teratur). Secara keseluruhan jenis tumbuhan di lokasi penelitian berdasarkan analisis indeks morishita diperoleh pola persebaran seragam (teratur), dimana indeks morishita < 1 . Menurut Mohfar (2012), kompetisi atau persaingan memengaruhi kemampuan individu untuk bertahan hidup dan bereproduksi.

Pola persebaran organisme di alam jarang yang ditemukan dalam pola yang seragam (teratur), tetapi populasi tumbuhan di alam pada umumnya mempunyai pola sebaran mengelompok (Puspanti, Widuri, Noorcahyati, Wibisono, \& Rengku, 2019).

Berdasarkan nilai indeks asosiasi (OI) antara F. tinctoria dengan tumbuhan yang memiliki INP $\geq 10 \%$ (Tabel 4), tingkat kekuatan asosiasi yang terbesar dimiliki oleh S. balangeran dan M. similis dengan nilai $\mathrm{OI}=0,63$, sedangkan kehadiran $\mathrm{F}$. angustifolia baik tingkat semai maupun pancang memiliki tingkat asosiasi rendah $(\mathrm{OI}=0,48-0,23)$. Tingkat asosiasi terendah $(\mathrm{OI}=<0,22)$ ditemukan 17 jenis diantaranya M. gigantea, M. paniculata, $\mathrm{P}$. urophyllum, F. parietalis, S. scorpioides, dan H. irya. Hal ini menunjukkan bahwa kedua tumbuhan (S. balangeran dan $\mathrm{M}$. similis) tersebut memiliki asosiasi yang semakin maksimum atau memiliki hubungan. Menurut Mayasari, Kinho, \& Suryawan (2012), jika OI semakin mendekati nilai 1, maka asosiasi akan semakin maksimum, sebaliknya jika semakin mendekati nilai 0 , maka tingkat asosiasi akan semakin minimum atau bahkan tidak ada hubungan. Secara ekologi, asosiasi antara dua tumbuhan sejenis atau bukan sejenis berawal dari tumbuh bersama dalam relung ekologi yang sama, hal ini menandakan bahwa asosiasi tidak mutlak dipengaruhi oleh kepadatan tiap jenis melainkan banyak faktor lain, mungkin acak pengaruhnya.

Fibraurea tinctoria dengan S. balangeran dan M. similis menunjukkan toleransi untuk hidup bersama pada area yang sama, atau ada hubungan timbal balik yang saling menguntungkan, khususnya pembagian ruang hidup. Asosiasi dapat terjadi karena faktor fisiologis atau morfologi tumbuhan dengan tumbuhan lain, juga faktor iklim mikro seperti cahaya dan suhu (Sirami, Caplat, Popy, Clamens, Arlettaz, Jiguet, Brotons, \& Martin, 2016). Kehadiran M. gigantea di lokasi penelitian sangat mudah tumbuh, bersimbiosis mutualisme dengan semut (Putri, Herwina, Satria, \& Handru, 2013) dan menghasilkan nutrisi (food body) untuk makanan semut, getah pada batang dioleskan sebagai obat luka (Nurhaida, Usma., \& Tavita, 2015; Nursanti, Novriyanti, \& Wulan, 2018) dan daun M. gigantea sebagai sumber pakan ternak ruminansia (kambing) oleh masyarakat lokal di Manokwari, Papua (Amirta, Angi, Ramadhan, Kusuma, \& Haqiqi, 2017). Selain itu, daun F. angustifolia sebagai bahan essential oil (Kalima, Suharti, Sumarhani, \& Trethowan, 2020). Keberadaan jenis-jenis tumbuhan yang berasosiasi terhadap akar kuning ( $\mathrm{F}$. tinctoria) ini sesuai hasil penelitian (Puspanti, Widuri, Noorcahyati, Wibisono, \& Rengku, 2019) menyatakan bahwa di KHDTK Samboja, Kalimantan Timur diketemukan jenis pohon yang berasosiasi terhadap F. tinctoria adalah berpotensi bahan baku obat yaitu jenis $F$. splendidisima, M. trichocarpa dan L. firma.

\section{KESIMPULAN DAN SARAN}

\section{A. Kesimpulan}

Potensi akar kuning (F. tinctoria) yang ditemukan di lokasi penelitian termasuk tinggi terutama untuk tingkat semai, dengan jumlah batang 375 individu/ha (6 batang) dan 
625 individu/ha (10 batang). Untuk tingkat pancang ditemukan empat dan tujuh batang atau 40 dan 70 individu/ha. F. tinctoria mempunyai peran penting sebagai bahan baku obat, hal ini ditunjukkan dengan nilai INP akar kuning yang cukup tinggi. Pola persebaran $F$. tinctoria di habitat alaminya memiliki pola sebaran seragam atau teratur. Indeks Asosiasi (OI) antara tumbuhan F. tinctoria dengan tumbuhan dominan sekitarnya menunjukkan kecenderungan tidak memiliki ketergantungan atau hubungan timbal balik berdasarkan sebaran jenis dengan jenis tumbuhan dominan yang saling menguntungkan, khususnya pembagian ruang hidup. Jenis $\mathrm{S}$. balangeran dan $\mathrm{M}$. similis memiliki asosiasi yang semakin maksimum atau memiliki hubungan timbal balik.

\section{B. Saran}

Potensi akar kuning (F. tinctoria) yang berukuran besar (tingkat pancang) di alam semakin menurun. Untuk itu perlu dilakukan peningkatan pemahaman petani atau pengumpul akar kuning untuk melakukan kegiatan budi daya akar kuning untuk mendukung ketersediaan bahan baku sehingga potensi di alam dapat ditingkatkan populasinya.

\section{UCAPAN TERIMA KASIH}

Penulis mengucapkan terima kasih kepada Kepala Pusat Penelitian dan Pengembangan Hutan, Dr. Ir. Kirsfianti Linda Ginoga, M.Sc., atas bantuan pembiayaan yang diberikan kepada penulis untuk menyelesaikan penelitian ini. Terima kasih juga kepada Kepala Dinas Kehutanan dan BKSDA Provinsi Kalimantan Tengah, serta penduduk desa yang membantu selama pekerjaan lapangan. Semua teknisi yang membantu kami dalam identifikasi jenis di Herbarium Botani dan Ekologi Hutan. Akhirnya kami ingin mengucapkan terima kasih yang tulus kepada Dr. Ir. Darwo, M.Si, Irma Yeni, S.P., M.Sc, dan Dewan Redaksi sebagai pengulas atas masukan, komentar, dan koreksi untuk memperbaiki naskah ini.

\section{DAFTAR PUSTAKA}

Ahmed, T., Gilani, A.U.H., Abdollahi, M., Daglia, M., Nabavi, S.F., \& Nabavi, S.M. (2015). Berberine and neurodegeneration: A review of literature. Pharmacological Reports, 67(5), $\quad 970 \quad-979$. https://doi.org/https://doi.org/10.1016/ j.pharep.2015.03.002

Amirta, R., Angi, E.M., Ramadhan, R., Kusuma, I.W., \& Haqiqi, M.T. (2017). Potensi pemanfaatan macaranga. (Kiswanto, Ed.) (September). Samarinda: Mulawarman University Press.

Badan Planologi Kehutanan. (2007). Rencana induk (master plan) rehabilitasi dan konservasi kawasan pengembangan lahan gambut rehabilitasi dan konservasi kawasan pengembangan lahan gambut. pusat rencana dan statistik kehutanan. Jakarta: Departemen Kahutanan.

Brandon, K. (2014). Ecosystem services from tropical forests: review of current science (CGD Climate and Forest Paper Series \#7 No. Working Paper 380). Washington, DC.

Brearley, F.Q., \& Banin, L.F (2016). The Ecology of the Asian dipterocarps. Plant Ecol Divers, 9(5-6), 429-436. https://doi.org/http://dx.doi.org/10.108 0/17550874.2017.1285363

Broto, B. (2015). Struktur dan komposisi vegetasi habitat anoa (Bubalus spp.) di Hutan Lindung Pegunungan Mekongga, Kolaka, Sulawesi Tenggara. In Seminar Nasional Masyarakat Biodiversitas Indonesia (pp. 615-620). Solo Jawa Tengah: Universitas Sebelas Maret, Solo, Jawa Tengah. https://doi.org/DOI: 10.13057/psnmbi/m010339

de Bruyn, M., Stelbrink, B., Morley, R., Hall, R., Carvalho, G., Cannon, C., van den Bergh, G., Meijaard, E., Metcalfe, 
I., Boitani, L., Maiorano, L., Shoup, R., \& Rintelen, A.T.W. (2014). Borneo and Indochina are major evolutionary hotspots for Southeast Asian Biodiversity. Systematic Biology, 63(6), 879-901.

Gaither, M.R. (2013). Origins of species richness in the Indo-Malay-Philippine biodiversity hotspot: evidence for the centre of overlap hypothesis. Journal of Biogeography, 40(9), 1638-1648. https://doi.org/https://doi.org/10.1111/ jbi.12126

Garsetiasih, R., Alikodra, H.S., Soekmadi, R., \& Bismark, M. (2012). Potensi dan produktivitas habitat pakan banteng (Bos javanicus d'Alton 1832) di Padang Rerumputan Pringtali dan Kebun Pantai Bandealit Taman Nasional Meru Bbetiri Jawa Timur. Jurnal Penelitian Hutan Dan Konservasi Alam, 9(2), 113-123. Retrieved from p3hka_pp@yahoo.co.id

Ghorbani, A., Langenberger, G., Feng, L., \& Sauerborn, J. (2011). Ethnobotanical study of medicinal plants utilised by Hani ethnicity in Naban River Watershed National Nature Reserve, Yunnan, China. Journal Ethnopharmacol, 134(3), 651$667 . \quad$ https://doi.org/DOI: 10.1016/j.jep.2011.01.011

Govaerts. (2001). World Checklist of Seed Plants Database in ACCESS E-F: 150919. Retrieved May 4, 2020, from http://plantsoftheworld.online/taxon/u rn:lsid:ipni.org:names:26937-

1\#bibliography.

Hidayat, S., Helmanto, H., Danang, D., Purnomo, W., \& Supriyatna, I. (2018). Habitat of Nepenthes spp. in the area of Sampit Botanic Gardens, Central Kalimantan, Indonesia. Biodiversitas, 19(4), 1258-1265. https://doi.org/DOI: 10.13057/biodiv/d190411

Indartik. (2009). Potensi pasar pulai sebagai sumber bahan baku industri obat herbal studi kasus Jawa Barat dan Jawa Tengah. Jurnal Penelitian Sosial Dan
Ekonomi Kehutanan, 2(2), 159-165.

Kalima, T., \& Denny. (2019). Komposisi jenis dan struktur hutan rawa gambut Taman Tasional Sebangau, Kalimantan Tengah. Jurnal Penelitian Hutan Dan Konservasi Alam, 16(1), 51-72.

https://doi.org/HTTPS://DOI.ORG/10 20886/PHKA.201916.1.51-72

Kalima, T., Suharti, S., Sumarhani, \& Trethowan, L. (2020). Tree species diversity and etnobotany of degraded peat swamp forest in Central Kalimantan. Reinwardtia, 19(1), 2754.

https://doi.org/DOI:10.14203/reinwar dtia.v19il.3819.

Karmilasanti, \& Fajri, M. (2020). Struktur dan komposisi jenis vegetasi di hutan sekunder: Studi Kasus KHDTK Labanan Provinsi Kalimantan Timur. Jurnal Penelitian Hutan Tanaman 17 (2), 69-85 ISSN: 1829-6327, E-ISSN: 2442

Kartawinata, K. (2010). Dua abad mengungkap kekayaan flora dan ekosistem indonesia.

Krebs, C.J. (1989). Ecological Methodology. (1st ed.). USA: Haeper and Publisher. New York.

Leksono, B. (2010). Teknik penunjukan dan pembangunan sumber benih. Balai Besar Penelitian dan Pengembangan Bioteknologi dan Pemuliaan Tanaman Hutan. Yogyakarta.

Lestariningsih, N., \& Setyaningsih, D. (2017). Explorative study of tropical pitcher plants (Nepenthes sp.) types and insects that trapped inside in Sebangau National Park Palangka Raya Central Kalimantan. Journal of Physics: Conf. Series, 795, 1-8. https://doi.org/doi:10.1088/17426596/795/1/012062

Ludwig, J.A., \& Reynolds, J. (1988). Statistical ecology: a primer on methods \& computing (1st ed.). John Wiley \& Sons, Inc.605 Third Ave. New York, United States.

Mayasari, A., Kinho, J.,\& Suryawan, A. 
(2012). Asosiasi eboni (Diospiros spp.) dengan jenis-jenis pohon dominan di Cagar Alam Tangkoko, Sulawesi Utara. Info BPK Manado, 2(1), 55-72.

Mohfar, R. (2012). Struktur tegakan dan sebaran jenis ramin dan meranti di hutan rawa gambut (studi kasus PT. Diamond Raya Timber dan PT Riau Andalan Pulp and Paper, Provinsi Riau. Retrieved from http://repository.ipb.ac.id/handle/1234 56789/61716

Mueller-Dombois, D \& Ellerberg, $\mathrm{H}$. (1974). Aims and methods of vegetation ecology. Canada. Retrieved from https://www.researchgate.net/ publication/259466952

Noorcahyati, Sulandjari, \& Dewi, W.S. (2016). Asosiasi akar kuning (Fibrourea tinctoria) dengan tumbuhan berpotensi obat di Samboja, Kalimantan Timur. Jurnal Hutan Tropis Volume, 4(3), 232-239.

Nurhaida, F.H., Usma., \& Tavita, G.E. (2015). Studi etnobotani tumbuhan obat di Dusun Kelampuk, Kecamatan Tanah Pinoh Barat, Kabupaten Melawi. Jutan Lestari, 3(4), 526 - 537.

Nursanti, Novriyanti, \& Wulan, C. (2018). Ragam jenis tumbuhan obat potensial di areal Hutan Kota Muhammad Sabki kota Jambi. Media Konservasi, 23(2), 169-177.

Ordonez, J.C., Luideling, E., Kindt, R., Tata, H.L., Harja, D., Jamnadass, R., \& Van Noordwijk, M. (2014). Constraints and opportunities for tree diversity management along the forest transition curve to achieve multifunctional agriculture. Current Opinion in Environmental Sustainability, 6, 54-60. https://doi.org/http://dx.doi.org/10.101 6/j.cosust.2013.10.009

Page, S.E., Rieley, J.O., Shotyk, W., \& Weiss, D. (1999). Interdependence of peat and vegetation in a Tropical PeatSwamp Forest. Philosophical transactions of the royal society of
London. Series B, Biological Sciences, 354(1391), 85-97.

https://doi.org/https://doi.org/10.1098/ rstb.1999.0529

Puspanti, A., Widuri, S. A., Noorcahyati, Wibisono, \& Rengku, M. (2019). Populasi dan asosiasi akar kuning (Fibraurea tinctoria Lour.) di KHDTK Samboja, Kalimantan Timur. In: Tata, M.H.L. (Ed.), Bunga rampe pengembangan hasil hutan bukan kayu Indonesia untuk mendukung bunga rampai sustainable development goals (1st ed., pp. 125-140). Bogor: IPB Press.

Putri, D. H., Herwina, R., Satria, \& Handru, A. (2013). Jenis-jenis semut (Hymenoptera: Formicidae) pada tumbuhan Macaranga spp. (Euphorbiaceae) di Hutan Pendidikan dan Penelitian Biologi Universitas Andalas. In Semirata FMIPA Universitas Lampung (pp. 217-221). Lampung: Universitas Lampung.

Rinaldi, S.E., Suryanto, \& Widuri, S.A. (2017). Informasi perdagangan akar kuning di Pasar Tradisional Martapura dan Pasar Tradisional Rantau, Kalimantan. Jurnal Sains Dan Kesehatan, 1(8), 434-439. https://doi.org/https://doi.org/10.2502 6/jsk.v1i8.58

Robiansyah, I. (2020). Shorea balangeran. https://doi.org/https://dx.doi.org/10.23 05/IUCN.UK.20201.RLTS.T33103A68072336.en

Roy, B., \& Giri, B.R. (2016). Carex baccans Nees, an anthelmintic medicinal plant of Northeast India. In Birla Kshetrimayum (Ed.), Medicinal Plants and its Therapeutic Uses (Junuari, pp. 2-22). USA: OMICS Group eBooks.

Setyawati, A. (2015). Struktur histologi hati, ginjal dan pankreas mencit (Mus Musculus) dengan perlakuan ekstrak batang akar kuning (Fibraurea tinctoria L.) selama organogenesis. Retrieved from htps://repository.ipb.ac.id/bitstream/h 
andle/123456789/79166/2015ase.pdf? sequence $=1 \& \quad \% 0 \mathrm{~A} \quad$ isAllowed $=\mathrm{y}$ $\% 0 \mathrm{~A}$

Sinaga, E., Tobing, I.S.L., \& Pravita, R.V. (2016). Pemanfaatan tumbuhan obat oleh Suku Dayak Iban Di Dusun Meliau Kalimantan Barat. Global Science Publishing House.

Sirami, C., Caplat, P., Popy, S., Clamens, A., Arlettaz, R., Jiguet, F., Brotons, L., \& Martin, J.L. (2016). Impacts of global change on species distributions: obstacles and solutions to integrate climate and land use. Global Ecology and Biogeography,

https://doi.org/DOI:10.1111/geb.1255 5

Soerianegara, I., \& Indrawan, A. (2008). Ekologi hutan Indonesia. (1st ed.). Bogor: Institue Pertanian Bogor.

Susila, I.W.W., Setiawan, O., \& Hidayatullah, M. (2019). Potensi dan habitat tempat tumbuh ketak (Lygodium circinnatum (Burn. F.)
Swartz) di Lombok. Jurnal Penelitian Hutan Tanaman 16(2), 103-114. ISSN: 1829-6327, E-ISSN: 2442-8930

Tata, H.L., \& Pradjadinata, S. (2016). Native species for degradaded peat swamp forest rehabilitation. Silvikultur Tropika, 7(3), 80-82.

Tudjuka, K., Ningsih, S, \& Toknok, B. (2014). Keanekaragaman jenis tumbuhan obat pada ragam jenis tumbuhan obat potensial kawasan hutan lindung di Desa Tindoli, Kecamatan Pamona Tenggara, Kabupaten Poso. Warta Rimba, 2(1), 120-128.

Turjaman, M., Faulina, S.A., Aryanto., Najmulah., Yani, A., \& Hidayat, A. (2019). Isolasi, indentifikasi, dan pemanfaatan fungi yang berasosiasi dengan Tristaniopsis obovata. Jurnal Penelitian Hutan dan Konservasi Alam, 16(1), 73-90. Retrieved from http://ejournal.forda-mof.org/ejournallitbang/index.php/JPHKA 
Lampiran (Appendix) 1. Rekapitulasi hasil analisis Indeks Nilai Penting fase semai pada jalur 1 (Recapitulation of Importance Value Index result of seedling phase at transect I)

\begin{tabular}{|c|c|c|c|c|c|c|}
\hline No. & Spesies (Species) & $\begin{array}{c}\text { Karapatan } \\
\text { (Density) } \\
\text { N/ha }\end{array}$ & $\begin{array}{c}\text { Kerapatan Relatif } \\
\text { (Relative Density) } \\
\text { (\%) }\end{array}$ & $\begin{array}{c}\text { Frekuensi } \\
\text { (Frequency) } \\
(\%)\end{array}$ & $\begin{array}{l}\text { Frekuensi Relatif } \\
\quad \text { (Relative } \\
\text { Frequency) (\%) }\end{array}$ & $\begin{array}{c}\text { Indek Nilai } \\
\text { Penting } \\
\text { (Important Value } \\
\text { Index) }(\%) \\
\end{array}$ \\
\hline 1 & Carex baccans Nees & 687,50 & 12,36 & 0,08 & 7,50 & 19,86 \\
\hline 2 & Freycinetia angustifolia Blume & 500,00 & 8,99 & 0,10 & 10,00 & 18,99 \\
\hline 3 & Shorea balangeran Burck & 437,50 & 7,87 & 0,10 & 10,00 & 17,87 \\
\hline 4 & Coleus amboinicus Lour. & 562,50 & 10,11 & 0,05 & 5,00 & 15,11 \\
\hline 5 & Fibraurea tinctoria Lour. & 375,00 & 6,74 & 0,08 & 7,50 & 14,24 \\
\hline 6 & Cryptocarya zollingeriana Miq. & 250,00 & 4,49 & 0,08 & 7,50 & 11,99 \\
\hline 7 & Diospyros bantamensis K.et V. & 187,50 & 3,37 & 0,08 & 7,50 & 10,87 \\
\hline 8 & Nephelium juglanifolium Blume & 312,50 & 5,62 & 0,05 & 5,00 & 10,62 \\
\hline 9 & Acronychia pedunculata (L.) Miq. & 250,00 & 4,49 & 0,05 & 5,00 & 9,49 \\
\hline 10 & Ficus indica $\mathrm{L}$. & 250,00 & 4,49 & 0,05 & 5,00 & 9,49 \\
\hline 11 & Ardisia villosa Roxb. & 375,00 & 6,74 & 0,03 & 2,50 & 9,24 \\
\hline 12 & Calophyllum sclerophyllum Vesque & 375,00 & 6,74 & 0,03 & 2,50 & 9,24 \\
\hline 13 & Asplenium nidus $\mathrm{L}$. & 187,50 & 3,37 & 0,05 & 5,00 & 8,37 \\
\hline 14 & $\begin{array}{l}\text { Ganua motleyana (de Vriese) Pierre ex. } \\
\text { Dubard. }\end{array}$ & 187,50 & 3,37 & 0,05 & 5,00 & 8,37 \\
\hline 15 & Dactylocladus stenostachys Oliv. & 125,00 & 2,25 & 0,05 & 5,00 & 7,25 \\
\hline 16 & Phalaenopsis amabilis Blume & 187,50 & 3,37 & 0,03 & 2,50 & 5,87 \\
\hline 17 & Stenochlaena palustris (Burm F) Bedd & 125,00 & 2,25 & 0,03 & 2,50 & 4,75 \\
\hline 18 & Tristaniopsis obovata Willson & 125,00 & 2,25 & 0,03 & 2,50 & 4,75 \\
\hline \multirow[t]{2}{*}{19} & Syzygium spicata Lamk. & 62,50 & 1,12 & 0,03 & 2,50 & 3,62 \\
\hline & & 5562,5 & 100 & 1,00 & 100 & 200,00 \\
\hline
\end{tabular}

Lampiran (Appendix) 2. Rekapitulasi hasil analisis Indeks Nilai Penting fase pancang pada jalur I (Recapitulation of Importance Value Index result of sapling phase at transect I)

\begin{tabular}{|c|c|c|c|c|c|c|c|c|c|}
\hline No & Spesies (Species) & $\begin{array}{c}\text { Karapatan } \\
\text { (Density) } \\
\text { (N/ha) }\end{array}$ & $\begin{array}{c}\text { Kerapatan } \\
\text { Relatif } \\
\text { (Relative } \\
\text { Density) } \\
(\%)\end{array}$ & $\begin{array}{l}\text { Frekuensi } \\
\text { (Frequency) }\end{array}$ & $\begin{array}{c}\text { Frekuensi } \\
\text { Relatif } \\
\text { (Relative } \\
\text { Frequency) } \\
\text { (\%) }\end{array}$ & $\begin{array}{c}\text { Luas Bidang } \\
\text { Dasar (Basal } \\
\text { area) }(\mathrm{m} 2)\end{array}$ & $\begin{array}{l}\text { Dominansi } \\
\text { (Dominance) }\end{array}$ & $\begin{array}{l}\text { Dominansi } \\
\text { Relatif } \\
\text { (Relative } \\
\text { Dominance) }\end{array}$ & $\begin{array}{c}\text { Indek Nilai } \\
\text { Penting } \\
\text { (Importance } \\
\text { Value Index) } \\
(\%)\end{array}$ \\
\hline 1 & $\begin{array}{l}\text { Tristaniopsis } \\
\text { obovata (R. Br.) } \\
\text { Peter G. Wilson \& } \\
\text { J.T. Waterh. }\end{array}$ & 170 & 10,00 & 0,08 & 6,52 & 0,03 & 0,33 & 13,54 & 30,06 \\
\hline 2 & $\begin{array}{l}\text { Shorea balangeran } \\
\text { Burck }\end{array}$ & 180 & 10,59 & 0,10 & 8,70 & 0,03 & 0,25 & 10,28 & 29,57 \\
\hline 3 & $\begin{array}{l}\text { Calophyllum } \\
\text { nodusum Vesque }\end{array}$ & 150 & 8,82 & 0,08 & 6,52 & 0,03 & 0,30 & 12,38 & 27,73 \\
\hline 4 & $\begin{array}{l}\text { Syzygium laxiflora } \\
\text { K.et V. }\end{array}$ & 90 & 5,29 & 0,20 & 17,39 & 0,01 & 0,07 & 3,02 & 25,70 \\
\hline 5 & $\begin{array}{l}\text { Campnosperma } \\
\text { auriculatum } \\
\text { (Blume) Hk.f. }\end{array}$ & 130 & 7,65 & 0,08 & 6,52 & 0,02 & 0,22 & 8,86 & 23,03 \\
\hline 6 & $\begin{array}{l}\text { Mangifera similis } \\
\text { Blume }\end{array}$ & 140 & 8,24 & 0,05 & 4,35 & 0,02 & 0,20 & 8,00 & 20,58 \\
\hline 7 & $\begin{array}{l}\text { Palaquium } \\
\text { cochlearia H.J.L }\end{array}$ & 110 & 6,47 & 0,05 & 4,35 & 0,02 & 0,18 & 7,35 & 18,17 \\
\hline 8 & $\begin{array}{l}\text { Nephelium } \\
\text { juglanifolium Blume }\end{array}$ & 110 & 6,47 & 0,08 & 6,52 & 0,01 & 0,11 & 4,62 & 17,61 \\
\hline 9 & $\begin{array}{l}\text { Syzygium spicata } \\
\text { Lamk. }\end{array}$ & 100 & 5,88 & 0,05 & 4,35 & 0,02 & 0,16 & 6,66 & 16,89 \\
\hline 10 & $\begin{array}{l}\text { Ardisia villosa } \\
\text { Roxb. }\end{array}$ & 90 & 5,29 & 0,08 & 6,52 & 0,01 & 0,11 & 4,29 & 16,11 \\
\hline 11 & $\begin{array}{l}\text { Ilex bogoriensis } \\
\text { Kds. }\end{array}$ & 100 & 5,88 & 0,08 & 6,52 & 0,01 & 0,08 & 3,12 & 15,52 \\
\hline 12 & $\begin{array}{l}\text { Freycinetia } \\
\text { angustifolia } \text { Blume }\end{array}$ & 80 & 4,71 & 0,05 & 4,35 & 0,02 & 0,15 & 6,21 & 15,26 \\
\hline
\end{tabular}


Potensi Akar Kuning (Fibraurea tinctoria Lour.) di Hutan

Rawa-Gambut, Kabupaten Kapuas, Provinsi Kalimantan Tengah

Titi Kalima

Lanjutan (To be continue)

\begin{tabular}{|c|c|c|c|c|c|c|c|c|c|}
\hline No & Spesies (Species) & $\begin{array}{c}\text { Karapatan } \\
\text { (Density) } \\
\text { (N/ha) }\end{array}$ & $\begin{array}{l}\text { Kerapatan } \\
\text { Relatif } \\
\text { (Relative } \\
\text { Density) } \\
(\%)\end{array}$ & $\begin{array}{c}\text { Frekuensi } \\
\text { (Frequency) }\end{array}$ & $\begin{array}{c}\text { Frekuensi } \\
\text { Relatif } \\
\text { (Relative } \\
\text { Frequency) } \\
(\%)\end{array}$ & $\begin{array}{c}\text { Luas } \\
\text { Bidang } \\
\text { Dasar } \\
\text { (Basal } \\
\text { area) } \\
(\mathrm{m} 2)\end{array}$ & $\begin{array}{c}\text { Dominansi } \\
\text { (Dominance) }\end{array}$ & $\begin{array}{l}\text { Dominansi } \\
\text { Relatif } \\
\text { (Relative } \\
\text { Dominance) }\end{array}$ & $\begin{array}{c}\text { Indek Nilai } \\
\text { Penting } \\
\text { (Importance } \\
\text { Value } \\
\text { Index) }(\%)\end{array}$ \\
\hline 13 & $\begin{array}{l}\text { Parastemon } \\
\text { urophyllum A.DC. }\end{array}$ & 50 & 2,94 & 0,05 & 4,35 & 0,01 & 0,09 & 3,83 & 11,12 \\
\hline 14 & $\begin{array}{l}\text { Cryptocarya } \\
\text { zollingeriana Miq. }\end{array}$ & 60 & 3,53 & 0,05 & 4,35 & 0,00 & 0,03 & 1,42 & 9,30 \\
\hline 15 & $\begin{array}{l}\text { Fibraurea tinctoria } \\
\text { Lour. }\end{array}$ & 40 & 2,35 & 0,05 & 4,35 & 0,01 & 0,05 & 2,19 & 8,89 \\
\hline 16 & $\begin{array}{l}\text { Syzygium } \\
\text { glabratum (DC.) } \\
\text { Veldkamp }\end{array}$ & 60 & 3,53 & 0,03 & 2,17 & 0,01 & 0,05 & 2,19 & 7,89 \\
\hline \multirow[t]{2}{*}{17} & $\begin{array}{l}\text { Dacryodes } \\
\text { costata (A.W.Benn.) } \\
\text { H.J.Lam }\end{array}$ & 40 & 2,35 & 0,03 & 2,17 & 0,01 & 0,05 & 2,04 & 6,57 \\
\hline & & 1.700 & 100,00 & 1,15 & 100,00 & 0,25 & 2,45 & 100,00 & 300,00 \\
\hline
\end{tabular}

Lampiran (Appendix) 3. Rekapitulasi hasil analisis Indeks Nilai Penting fase semai pada jalur II (Recapitulation of Importance Value Index result of seedling phase at transect II)

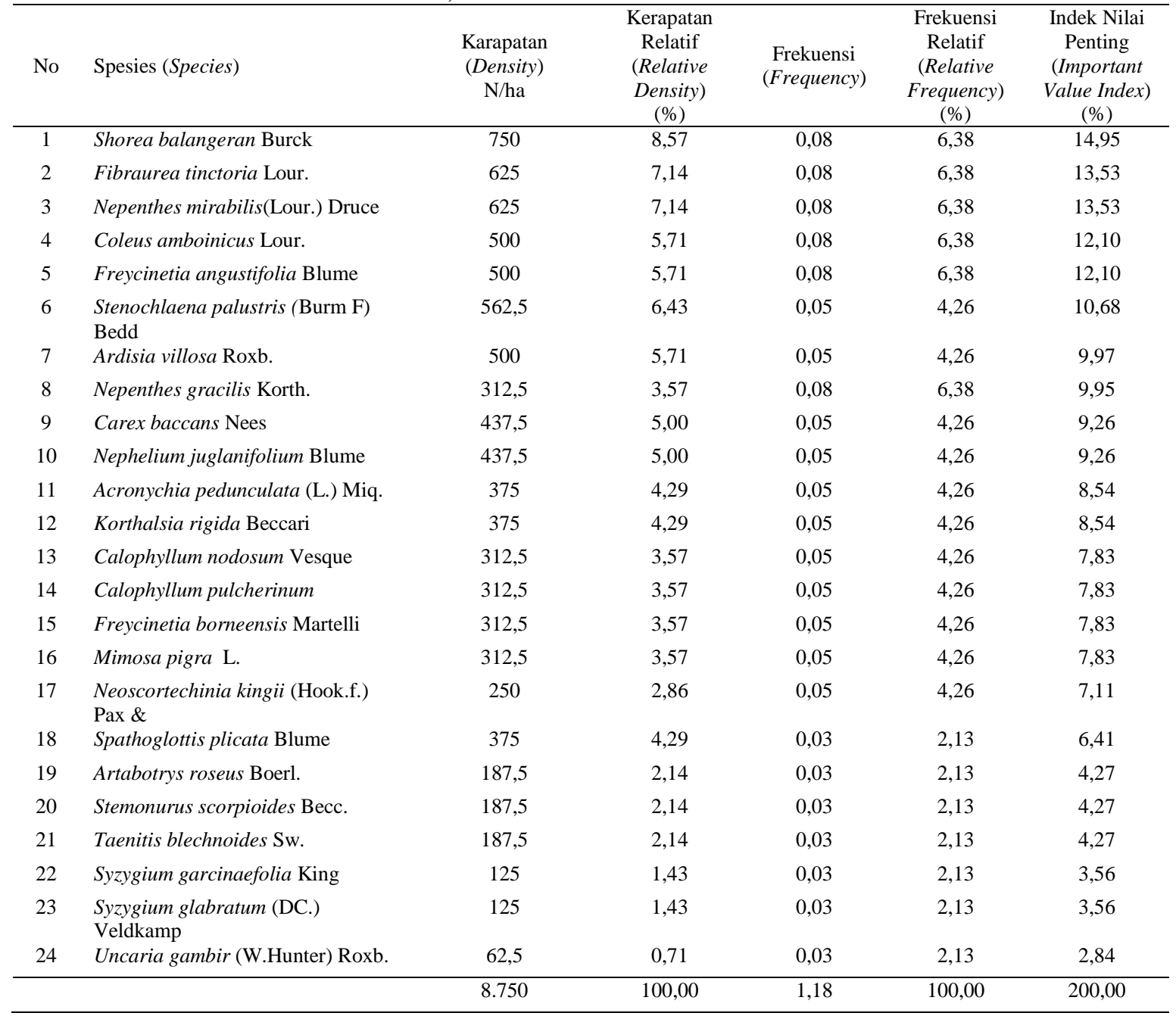


Lampiran (Appendix) 4. Rekapitulasi hasil analisis Indeks Nilai Penting fase pancang pada jalur II (Recapitulation of Importance Value Index result of sapling phase at transect II)

\begin{tabular}{|c|c|c|c|c|c|c|c|c|c|}
\hline No & Spesies (Species) & 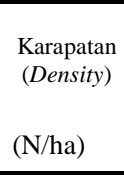 & $\begin{array}{c}\text { Kerapatan } \\
\text { Relatif } \\
\text { (Relative } \\
\text { Density) } \\
(\%)\end{array}$ & $\begin{array}{l}\text { Frekuensi } \\
\text { (Frequency) }\end{array}$ & $\begin{array}{c}\text { Frekuensi } \\
\text { Relatif } \\
\text { (Relative } \\
\text { Frequency) } \\
(\%)\end{array}$ & $\begin{array}{c}\text { Lu as } \\
\text { Bidang } \\
\text { Dasar } \\
\text { (Basal } \\
\text { area) } \\
(\mathrm{m} 2) \\
\end{array}$ & $\begin{array}{c}\text { Dominansi } \\
\text { (Dominance) }\end{array}$ & $\begin{array}{c}\text { Dominansi } \\
\text { Relatif } \\
\text { (Relative } \\
\text { Dominance) } \\
(\%)\end{array}$ & $\begin{array}{c}\text { Indek Nilai } \\
\text { Penting } \\
\text { (Importance } \\
\text { Value } \\
\text { Index) } \\
(\%) \\
\end{array}$ \\
\hline 1 & $\begin{array}{l}\text { Macaranga gigantea (Reichb.f. } \\
\text { \& Zoll.) Müll.Arg. }\end{array}$ & 130 & 11,93 & 0,1 & 10 & 0,032 & 0,425 & 11,10 & 33,03 \\
\hline 2 & Syzygium garcinaefolia King & 120 & 11,01 & 0,075 & 7,5 & 0,013 & 0,511 & 13,36 & 31,87 \\
\hline 3 & Shorea balangeran Burck & 90 & 8,257 & 0,1 & 10 & 0,028 & 0,486 & 12,71 & 30,97 \\
\hline 4 & $\begin{array}{l}\text { Acronychia pedunculata (L.) } \\
\text { Miq. }\end{array}$ & 100 & 9,174 & 0,075 & 7,5 & 0,005 & 0,429 & 11,22 & 27,89 \\
\hline 5 & $\begin{array}{l}\text { Calophyllum pulcherrinum } \\
\text { Wall. ex Choisy }\end{array}$ & 80 & 7,339 & 0,075 & 7,5 & 0,007 & 0,290 & 7,58 & 22,42 \\
\hline 6 & Korthalsia rigida Beccari & 110 & 10,09 & 0,075 & 7,5 & 0,003 & 0,055 & 1,44 & 19,03 \\
\hline 7 & $\begin{array}{l}\text { Xanthophyllum ellipticum. } \\
\text { Korth. ex Miq. }\end{array}$ & 60 & 5,505 & 0,075 & 7,5 & 0,007 & 0,228 & 5,97 & 18,97 \\
\hline 8 & Fibraurea tinctoria Lour. & 70 & 6,422 & 0,075 & 7,5 & 0,010 & 0,172 & 4,51 & 18,43 \\
\hline 9 & Murraya paniculata Jack. & 60 & 5,505 & 0,05 & 5 & 0,004 & 0,247 & 6,46 & 16,97 \\
\hline 10 & Parastemon urophyllum A.DC. & 40 & 3,67 & 0,05 & 5 & 0,003 & 0,182 & 4,76 & 13,43 \\
\hline 11 & Ficus parietalis Blume & 50 & 4,587 & 0,05 & 5 & 0,009 & 0,146 & 3,82 & 13,41 \\
\hline 12 & $\begin{array}{l}\text { Stemonurus scorpioides } \\
\text { Beccari }\end{array}$ & 40 & 3,67 & 0,05 & 5 & 0,004 & 0,169 & 4,42 & 13,09 \\
\hline 13 & $\begin{array}{l}\text { Horsfieldia irya (Blume) } \\
\text { Warb. }\end{array}$ & 50 & 4,587 & 0,05 & 5 & 0,009 & 0,090 & 2,34 & 11,93 \\
\hline 14 & $\begin{array}{l}\text { Diospyros bantamensis K.et } \\
\text { V. }\end{array}$ & 30 & 2,752 & 0,025 & 2,5 & 0,013 & 0,129 & 3,38 & 8,63 \\
\hline 15 & Ilex bogoriensis Kds. & 20 & 1,835 & 0,025 & 2,5 & 0,011 & 0,106 & 2,77 & 7,10 \\
\hline 16 & $\begin{array}{l}\text { Pittosporium pentandrum } \\
\text { (Blanco) Merr. }\end{array}$ & 20 & 1,835 & 0,025 & 2,5 & 0,010 & 0,101 & 2,65 & 6,98 \\
\hline \multirow[t]{2}{*}{17} & Mangifera similis Blume & 20 & 1,835 & 0,025 & 2,5 & 0,003 & 0,058 & 1,51 & 5,85 \\
\hline & & 1090 & 100,00 & 1,00 & 100,00 & 0,1711 & 3,82 & 100,00 & 300,00 \\
\hline
\end{tabular}

